\title{
Inflammation in epileptogenesis after traumatic brain injury
}

Kyria M. Webster ${ }^{1}$, Mujun Sun ${ }^{1}$, Peter Crack ${ }^{2}$, Terence J. O'Brien', Sandy R. Shultz ${ }^{1}$ and Bridgette D. Semple ${ }^{1 *}$

\begin{abstract}
Background: Epilepsy is a common and debilitating consequence of traumatic brain injury (TBI). Seizures contribute to progressive neurodegeneration and poor functional and psychosocial outcomes for TBI survivors, and epilepsy after TBI is often resistant to existing anti-epileptic drugs. The development of post-traumatic epilepsy (PTE) occurs in a complex neurobiological environment characterized by ongoing TBl-induced secondary injury processes. Neuroinflammation is an important secondary injury process, though how it contributes to epileptogenesis, and the development of chronic, spontaneous seizure activity, remains poorly understood. A mechanistic understanding of how inflammation contributes to the development of epilepsy (epileptogenesis) after TBI is important to facilitate the identification of novel therapeutic strategies to reduce or prevent seizures.

Body: We reviewed previous clinical and pre-clinical data to evaluate the hypothesis that inflammation contributes to seizures and epilepsy after TBI. Increasing evidence indicates that neuroinflammation is a common consequence of epileptic seizure activity, and also contributes to epileptogenesis as well as seizure initiation (ictogenesis) and perpetuation. Three key signaling factors implicated in both seizure activity and TBI-induced secondary pathogenesis are highlighted in this review: high-mobility group box protein-1 interacting with toll-like receptors, interleukin-1 $\beta$ interacting with its receptors, and transforming growth factor- $\beta$ signaling from extravascular albumin. Lastly, we consider age-dependent differences in seizure susceptibility and neuroinflammation as mechanisms which may contribute to a heightened vulnerability to epileptogenesis in young brain-injured patients.

Conclusion: Several inflammatory mediators exhibit epileptogenic and ictogenic properties, acting on glia and neurons both directly and indirectly influence neuronal excitability. Further research is required to establish causality between inflammatory signaling cascades and the development of epilepsy post-TBI, and to evaluate the therapeutic potential of pharmaceuticals targeting inflammatory pathways to prevent or mitigate the development of PTE.
\end{abstract}

Keywords: Inflammation, Traumatic brain injury, Epilepsy, Post-traumatic epilepsy, Seizures, Cytokine, Interleukin, Astrocytes

\section{Background}

Epilepsy is a common and debilitating consequence of traumatic brain injuries (TBI), with recurrent spontaneous seizures contributing to progressive neurodegeneration and greatly interfering with quality of life as well as increasing the risk of injury and death. Epileptogenesis, the neurobiological process by which epilepsy develops, occurs as part of the ongoing secondary injury

\footnotetext{
* Correspondence: Bridgette.Semple@unimelb.edu.au

${ }^{1}$ Department of Medicine (The Royal Melbourne Hospital), The University of Melbourne, Kenneth Myer Building, Melbourne Brain Centre, Royal Parade, Parkville, VIC 3050, Australia

Full list of author information is available at the end of the article
}

events triggered by a brain insult, including neuroinflammation. Previous evidence from clinical and preclinical studies has suggested that aspects of the inflammatory response may also promote seizure activity itself (ictogenesis).

The aim of this review was to evaluate the published evidence regarding the role of inflammation in the development of post-traumatic epilepsy (PTE), drawing upon data from both clinical studies and experimental models. In particular, we summarize the current understanding of mechanisms by which neuroinflammatory mediators can influence neuronal excitability, either directly or indirectly. We focused in particular on three 
key signaling pathways which are known to be involved in TBI-induced secondary pathogenesis, and more recently, have been implicated in seizure activity and the process of epileptogenesis. Lastly, potential mechanisms underlying age-specific vulnerability to hyperexcitability and epileptogenesis are discussed. This review also acts to highlight knowledge gaps in the field, identifying key areas for future research. Ultimately, a mechanistic understanding of how neuroinflammation contributes to the development of epilepsy after brain injury may identify novel therapeutic targets, to reduce or prevent PTE for survivors of brain injuries.

\section{Traumatic brain injury and epilepsy}

TBI is a major global public health problem and a leading cause of mortality and morbidity $[1,2]$. It is particularly prevalent in childhood and adolescence, as a result of falls, inflicted trauma, sports-related injuries, and motor vehicle accidents. An earlier review of 11 studies examining TBI incidence in Australia, North America, and Europe estimated a median of 691 injuries per 100,000 population under 20 years of age [2]. Of note, children under the age of 5 had the highest incidence of Emergency Department admissions for TBI [2].

TBI is any insult to the brain from an external mechanical force, including penetrative or blunt trauma [1,3]. These can include focal injuries, such as lesions caused by contusions or hemorrhages, or diffuse injuries, such as with traumatic axonal injury [4]. TBI involves a primary insult, defined as the immediate structural damage caused by the external mechanical force. This is followed by a secondary injury, which includes a myriad of neuropathological processes including excitotoxicity, neuroinflammation, oxidative stress, and apoptosis $[1,3$, 5]. These secondary processes commence within minutes after TBI, can persist for months to years, and are thought to contribute to the expansion of tissue damage $[6,7]$. The manifestation and severity of secondary injury processes can differ depending on injury type, severity, and individual factors [8]. The biomechanics and biochemical components of the physiological response to TBI have been reviewed in detail elsewhere $[7,9]$.

PTE is a common consequence of TBI, defined as spontaneous, recurrent, and chronic seizures following a head injury [10, 11]. Clinical diagnosis is often based upon one or more unprovoked seizures occurring later than 1 week after a TBI, as an indicator that epileptogenesis is occurring [12]. Epileptogenesis is the process by which epilepsy develops; that is, when an otherwise normally functioning brain becomes biased towards abnormal recurrent electrical activity, increasing the propensity to develop spontaneous recurrent seizures [13, 14]. It is thought to develop through three phases: (1) the initial trigger; (2) the latency period, during which the changes initiated in phase one cause a transformational bias in the brain towards epileptic activity; and (3) the onset of spontaneous seizures and the establishment of chronic epilepsy (Fig. 1) [15-18]. After TBI, the

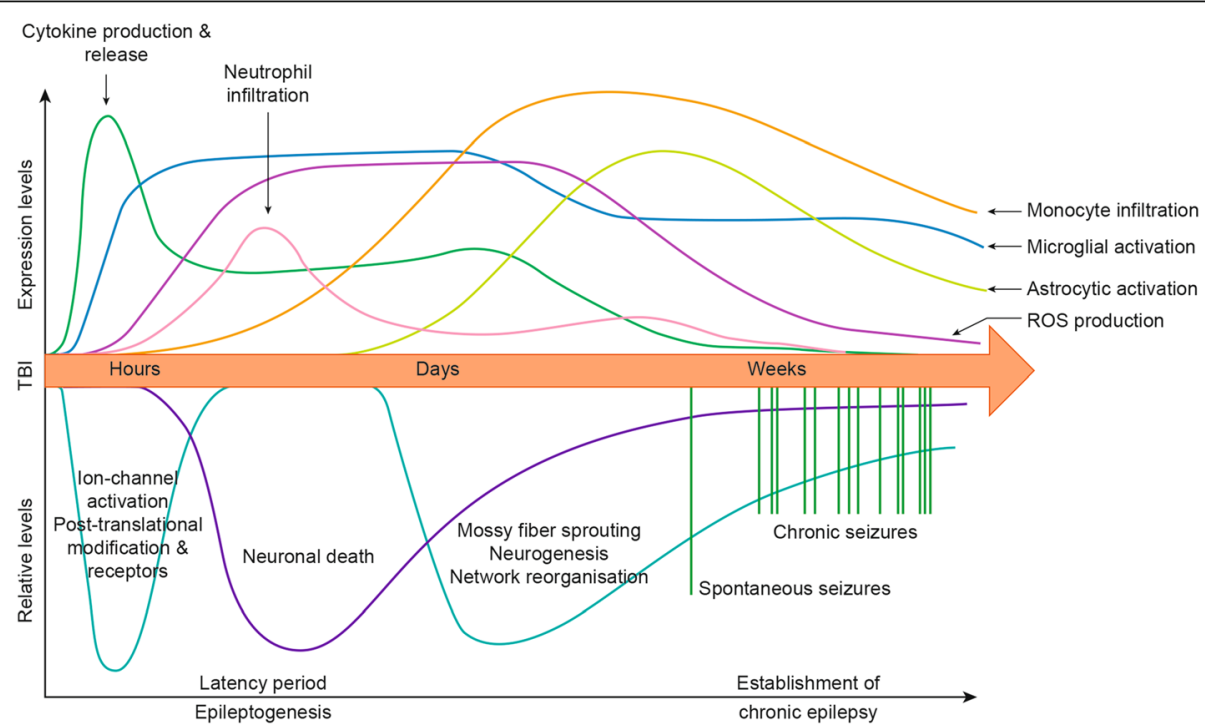

Fig. 1 Summary of the progression of inflammatory factors and epileptogenesis after TBI. After TBI, epileptogenesis occurs after a latent period of months to years. Within hours after the injury, a myriad of cytokines are released at high levels which can continue for days. This is concurrent with activation of ion-channels and post-translational modifications of various receptors associated with neuronal excitation and inhibition, which can occur as early as minutes after the injury. Local immune cells are activated, and peripheral immune cells are also recruited to the area within hours to days. Neuroinflammation can persist for weeks after the injury, coincidental with widespread neuronal loss. In the later phase of epileptogenesis, processes such as neurogenesis and mossy fiber sprouting in the hippocampus contribute to an increasingly excitable neuronal environment. It may be weeks, months, or years before spontaneous seizures and the establishment of chronic and persistent epilepsy manifests 
latency period may be many years in duration, and epileptogenesis is associated with ongoing secondary injury processes which can bias towards hyperexcitability [14].

The reported incidence of developing epilepsy after TBI ranges from 4.4 to $53 \%$, depending on the population studied [12]. There are several factors that have been associated with a greater risk of developing PTE, including higher injury severity and a lower age-at-insult $[10,19,20]$. It has been estimated that $10-20 \%$ of children with severe TBI develop PTE, although the risk after injury has been reported at up to $60 \%$, with the wide range of estimates most likely due to the large variation in severity, heterogeneity of the initial insult, and difficulties in diagnosis and follow-up [10, 20]. Children under the age of 5 may be at highest risk for early posttraumatic seizure development $[10,12,21]$, with one study finding that this age group were more likely to have a seizure within the first week after injury (17\%), compared to patients over 5 years of age with similar injuries (2\%) [22]. In adults, the presence of acute intracerebral hematoma has been consistently associated with a higher risk of developing PTE, as are penetrative insults and depressed skull fractures [12, 22, 23].

Several neuropathological hallmarks have been associated with the development of PTE. An early and persistent increase in hippocampal excitability has been observed in both patients and animal models [24]. This net increase in excitability is thought to result from the selective loss of vulnerable inhibitory interneurons concurrent with the reorganization of excitatory circuitry $[25,26]$. Recurrent excitatory circuitry in the hippocampal dentate gyrus may manifest as mossy fiber sprouting, where the axons of dentate granule cells form abnormal connections with neighboring neurons in response to a loss of CA3 pyramidal cell targets and hilar interneurons $[27,28]$.

The onset of PTE is also commonly associated with hippocampal sclerosis, involving the loss of pyramidal neurons, and concurrent reactive gliosis, consistent with temporal lobe epilepsy (TLE) [29]. An estimated 35-62\% of patients with PTE have seizures originating from the temporal lobe [30, 31]. However, overlaying cortical regions have also been implicated in post-TBI epileptogenesis, as these regions may also exhibit neuronal loss, chronic neuroinflammation, and network reorganization resulting in spontaneous epileptiform activity [26, 32].

Clinical management and treatment of PTE is challenging, as seizures are commonly resistant to existing antiseizure drugs (ASDs) [10, 20, 33, 34]. Classical ASDs, such as phenytoin, carbamazepine, valproate benzodiazepines, are ineffective in reducing or preventing PTE [34-36]. While early post-injury prophylaxis with ASDs may reduce or prevent early post-injury seizures [37], there is little evidence to indicate that these treatments can be disease-modifying and prevent the development of PTE or spontaneous unprovoked seizures long-term [38]. Once a patient has developed seizures, polypharmacy is often employed in an attempt to control the seizures, yet a significant proportion of TBI patients who develop epilepsy will develop drug-resistance, defined as a failure to achieve seizure cessation after trialling more than two tolerated and appropriate ASD treatments [33, 34]. However, the use of multiple ASDs simultaneously could have unpredictable consequences due to potential interactions with various secondary processes and the reduced cerebral perfusion commonly present after TBI [20]. Seizures are particularly detrimental during periods of brain development as they can cause permanent adverse effects, including cognitive deficits $[39,40]$. Due to increased susceptibility to post-traumatic seizures after an early age-of-insult, as well as inherent difficulties in controlling or treating PTE, further research is needed to understand the mechanisms that contribute to the generation of post-traumatic seizures, particularly in pediatric age groups.

\section{Neuroinflammation after TBI}

Inflammation is a central component of the secondary injury after TBI, and the subject of intense research as a promising target for treatment. In healthy tissue, inflammation typically acts to combat invading pathogens and preserve the health of the tissue [41]. However, in pathological conditions such as trauma, inflammation can also function as a reactionary system to either aggravate or ameliorate tissue damage [42, 43]. Increased neuroinflammation after TBI has been associated with poor outcomes and progression to various sequelae including neurodegenerative diseases [43-47].

The main hallmarks of the cerebral inflammatory response after TBI include blood-brain barrier (BBB) dysfunction, edema, microglial, and astrocytic activation and migration, the release of inflammatory factors such as cytokines and the recruitment of blood-derived leukocytes into brain parenchyma [48]. Neutrophils, recruited from the peripheral circulation within hours after TBI, mediate early pathogenesis by promoting edema and oxidative stress, and the production of inflammatory cytokines and neurotoxic proteases [49, 50]. Cytokines can be released rapidly after injury as they are synthesized and stored locally by neurons and glia [48].

Under physiological conditions, the BBB is a highly stringent barrier between vessels and brain tissue, which mediates the transport of blood components such as immune cells into the brain [51]. After TBI, this barrier can be compromised, allowing peripheral inflammatory cells into the brain and the injured area [52]. Chemoattractant cytokines, called chemokines, further facilitate the recruitment and transmigration 
of inflammatory leukocytes [53]. By their actions at the $\mathrm{BBB}$ as well as direct chemoattraction, chemokines including CXCL8 and CCL2 (also known as monocyte chemoattractant protein-1) are key mediators in the migration of neutrophils and monocytes, respectively, to the site of injury [54].

Once in the brain, these cells release a plethora of inflammatory cytokines, chemokines, and reactive oxygen species (ROS) to perpetuate inflammation and oxidative stress in the injured brain. Both clinical and experimental studies have demonstrated a pronounced elevation of many cytokines after TBI, including tumor necrosis factor (TNF- $\alpha$ ), transforming growth factor- $\beta$ (TGF- $\beta$ ), and interleukin- $1 \beta$

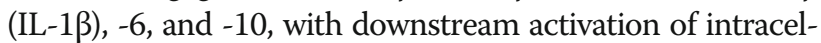
lular signaling cascades involving nuclear factor Kappalight-chain-enhancer of activated B cells (NF-кB) [1, 44, 48, 55-57]. Released cytokines in turn can recruit additional blood-borne neutrophils and monocytes into the injured tissue, propagating the inflammatory cascade.

Inflammation in the brain has a duality in function after injury, which manifests through the actions of many different cell types. For example, microglial activation is integral in tissue repair, surveillance of pathogenic factors and host defense [58]. However, activated microglia can also release cytotoxic factors such as ROS to induce oxidative stress [59-61]. Astrocytes can promote tissue repair in the central nervous system (CNS) through the release of insulin-like growth factor [47], but are also implicated in the perpetuation of inflammation by an over-production of cytokines such as IL-6 $[62,63]$, as well as modulation of the BBB and neuronal function to promote excitability and seizure production [64].

Cytokines themselves also have a complex role after TBI, as experimental studies have yielded conflicting findings of both deleterious contributions and participation in repair processes after CNS insult [48]. One cytokine that displays such paradox is TNF- $\alpha$, which has been associated with increased neurological damage, including demyelination and BBB breakdown, in several experimental models of TBI $[65,66]$. However, increased levels of TNF- $\alpha$ may conversely have a neuroprotective function in the late stages of inflammation post-TBI, at 2-4 weeks after the injury, as suggested from a mouse model of TBI [56]. The varied roles of inflammatory mediators in the pathological environment after TBI is likely dependent on many different factors, including timing of release, the location and cell types involved, the differing physics of protein-protein interactions of cytokines, and their relative amounts. The multifarious dynamics of this response may contribute to the progression of a chronic state of damage, leading to the myriad of secondary consequences of TBI, including PTE.

\section{Inflammation in epileptogenesis}

The long-standing concept that seizures result from an imbalance between reduced $\gamma$-aminobutyric acid (GABA)-ergic inhibition and enhanced glutamatergic excitation $[67,68]$, based upon the presence of large amplitude EEG discharges during the seizure event itself, is an over-simplified of a very complex network response. While excessive glutamatergic excitation has historically been considered of as the precipitating factor for a focal seizure, there is a lack of strong data to support this hypothesis. Instead, paradoxically, accumulating evidence indicates that increased synchronised GABAergic interneuronal activity is sufficient to disrupt neuronal networks and initiate the transition from interictal to ictal activity resulting in focal seizures [69]. The recruitment of neighboring neurons and subsequent seizure progression is then hypothesized to be mediated by an elevation in extracellular potassium [70]. Adding to the complexity of network-based activity, both excitatory and inhibitory roles of GABA and glutamatergic neurons have been reported, and a range of extrasynaptic as well as synaptic neurotransmitter receptors and ion channels have been implicated in seizures, in addition to those traditionally implicated, such as NMDA and $\mathrm{GABA}_{\mathrm{A}}$ receptors [71].

However, strong evidence also implicates a role for inflammation in seizure pathologies [45]. Seizure activity readily induces an inflammatory response, including the activation of microglia and production of proinflammatory cytokines [47, 63]. More importantly, experimental data has suggested that inflammatory mediators may initiate or trigger early seizures, preceding the onset of diagnosed epilepsy. For example, systemic inflammation by injection of bacterial lipopolysaccharide results in a lowered seizure threshold [72]. In the next sections, we will review clinical and experimental evidence suggesting an inherent link between inflammatory signaling, neuropathology, and seizure activity in the injured brain, as a likely mechanism of importance in the development and progression of PTE.

\section{Seizures increase inflammation}

Experimentally, induction of a seizure induces the rapid activation of glial cells in surrounding parenchyma, which respond by the production and release of inflammatory molecules [73]. Much of the research that has shown an increase in inflammation after seizures have used experimental models of status epilepticus. This involves the administration of a chemical or electrical pro-convulsant stimulus to create a sustained seizure event (the initial insult) followed by a latency period before the onset of spontaneous recurrent seizures to model epilepsy [74, 75]. In these experimental models, the inflammatory response displays a distinct temporal 
profile after induction, characterized by the early activation of astrocytes and microglia followed by BBB breakdown and neuronal activation [63, 76, 77]. In addition to the investigation of protein release, microarray analysis of gene transcripts have also demonstrated an upregulation of inflammatory genes [78]. Specific cell surface toll-like receptors (TLR's), which respond to a range of inflammatory cytokines and other stress-related factors, are highly upregulated after pilocarpine-induced seizures on forebrain microglia of adult mice [77]. Simultaneously, a robust increase in cytokine levels has been observed in both chemically and electrically induced experimental models of epilepsy in adult rodents $[77,79,80]$. For example, IL- $1 \beta$ is expressed at low levels in a healthy brain, but is robustly upregulated for up to 60 days after the induction of self-sustaining limbic status epilepticus in rodents, a model using hippocampal electrical stimulation [76]. TNF- $\alpha$ and IL-6 are also rapidly upregulated after status epilepticus, peaking within $30 \mathrm{~min}$ of seizure onset and remaining elevated for up to $72 \mathrm{~h}$ in rats that progressed to spontaneous seizures [76].

These experimental findings that seizures result in inflammation are confirmed by evidence in the clinical setting. Analysis of cerebrospinal fluid (CSF) from newly diagnosed adult patients with tonic-clonic seizures detected an upregulation of IL-6 and IL-1 receptors (IL1Rs) [81, 82]. Matched serum samples revealed a higher levels of IL-6 compared to in the CSF, suggesting that these cytokines likely originated in the brain [82]. High levels of cytokines including IL- $1 \beta$ and high-mobility group box protein-1 (HMGB1) have also been identified in neurons and glia of surgically resected epileptic tissue [83]. Together, these findings indicate that neuroinflammation is a common consequence of seizure activity.

\section{Inflammation contributing to seizures}

Accumulating evidence suggests that neuroinflammation is also a contributor to epileptogenic pathology after TBI [45, 63, 84]. In particular, experimental models have demonstrated that glial cell activation and recruitment and the synthesis of inflammatory factors, may precede and/or occur concurrently with epileptogenic events [85, 86]. For example, in a rodent model of experimental TBI, a reduced threshold to electroconvulsive shockinduced seizures was reversed when minocycline, a tetracycline antibiotic known to inhibit brain infiltration of monocytes and microglia, was applied [87, 88], implicating both microglial activity and pro-inflammatory cytokines in post-traumatic seizure activity.

Much of the evidence for a role of inflammation in epileptogenesis has focused on the effect of cytokines in seizure susceptibility. Cytokines can act as classical neurotransmitters through receptor modulation and phosphorylation at the neuronal membrane [89]. Models of chronic inflammation, such as transgenic mice systemically overexpressing IL- 6 or TNF- $\alpha$, can reduce seizure threshold and predispose the brain to seizure induced-neuronal loss $[90,91]$. Indeed, inflammatory signaling may promote the loss of GABAergic neurons in the hippocampus, resulting in an increased propensity for seizures due to a reduction in synaptic inhibition [92].

$\mathrm{N}$-methyl-D-aspartate (NMDA) receptors play a critical role in the glutamatergic system to contribute to neuronal excitability, and previous evidence suggests both direct and indirect interactions between these receptors and cyokines [93]. Cytokines have been found to inhibit the uptake of glutamate by astrocytes in culture [94] and modulate excitatory neurotransmission in the brain through NMDA and alpha-amino-3-hydroxyl-5-methyl-4-isoxazole-propoinate (AMPA) receptors $[95,96]$. For example, IL- $1 \beta$ produced by microglia can enhance NMDA-mediated $\mathrm{Ca}^{2+}$ currents through cell surface type 1 IL-1R (IL-1R1) co-localized on pyramidal cell dendrites [89]. Pre-synaptic NMDA receptors are agonists for $\mathrm{Ca}^{2+}$-mediated glutamate release, and when activated by inflammatory factors such as IL-1 $\beta$ and HMGB1 can cause an excess of intracellular $\mathrm{Ca}^{2+}$ leading to an extracellular hyperexcitability and excitotoxicity [95]. Several other cytokines including TNF- $\alpha$ and IL-10 have also been associated with the regulation of seizure duration in experimental kindling models [97, 98]. Though these correlations have been seen in multiple studies with different models, the mechanisms underlying the relationship between the inflammatory environment and epileptogenesis, particularly in the context of brain injury, remain still poorly understood.

There is limited clinical data to confirm a cause-andeffect link between inflammation and the pathophysiology of epilepsy, however increasing evidence supports this hypothesis. Many studies have now demonstrated that early exposure of the brain to immune responses can have varied and persistent consequences on adult physiology [99-102]. Febrile seizures (FS) and febrile status epilepticus in children is a risk factor for developing epilepsy later in life [103], which may be induced by fever often associated with inflammation and infection [47]. Although the mechanisms underlying FS remains unclear, it is thought that cytokines play a key role in its development [104]. One study has reported specific polymorphisms in the promoter region of cytokine genes, including $\mathrm{IL}-1 \beta$, in children with FS compared to controls [105]. Such genetic variation may influence the production of IL-1 $\beta$ in both healthy tissue and after injury or stimulus [106], and similar polymorphisms have also been observed at a high frequency in patients with TLE [107].

Recently, the hypothesis of glial functions playing a pivotal role in biasing the neuronal network towards an 
epileptogenic environment has been gaining traction $[108,109]$. In particular, interactions between neurons, glia, and the inflammatory mediators IL-1 $\beta$, HMGB-1, and TGF- $\beta$, have been implicated in promoting seizure susceptibility, as described below. The main signaling pathways implicated in the proposed link between inflammation and epileptogenesis of these three mediators is summarized in Fig. 2.

\section{IL-1 $\beta /$ IL-1R signaling in TBI and PTE}

IL-1 is a family of pro-inflammatory cytokines that act as key mediators of the innate immune response [110]. The IL-1 family consists of 7 agonists (e.g., IL- $1 \alpha$ and $\beta$ ) and 3 receptor antagonists [110], and amongst these the IL-1 $\beta$ isoform has been the most commonly studied in the brain injury and epilepsy settings. In the CNS, IL- $1 \beta$ can be produced by a range of cells including microglia, astrocytes, endothelial cells (EC), neurons, and peripheral leukocytes upon infiltrating into the brain [111-113]. IL-1 $\beta$ exerts its action on multiple cell types primarily via IL-1R1 [114-119]. This initiates intracellular signaling via NF- $\mathrm{kB}$ transcription factor, p38 mitogenactivated protein kinase (MAPK), or other factors $[118,120]$. Several studies have demonstrated that IL-1 $\beta$ binding to IL-1R stimulates immune cell activation and induces the production of neurotoxic molecules [114, 115, 117-119].

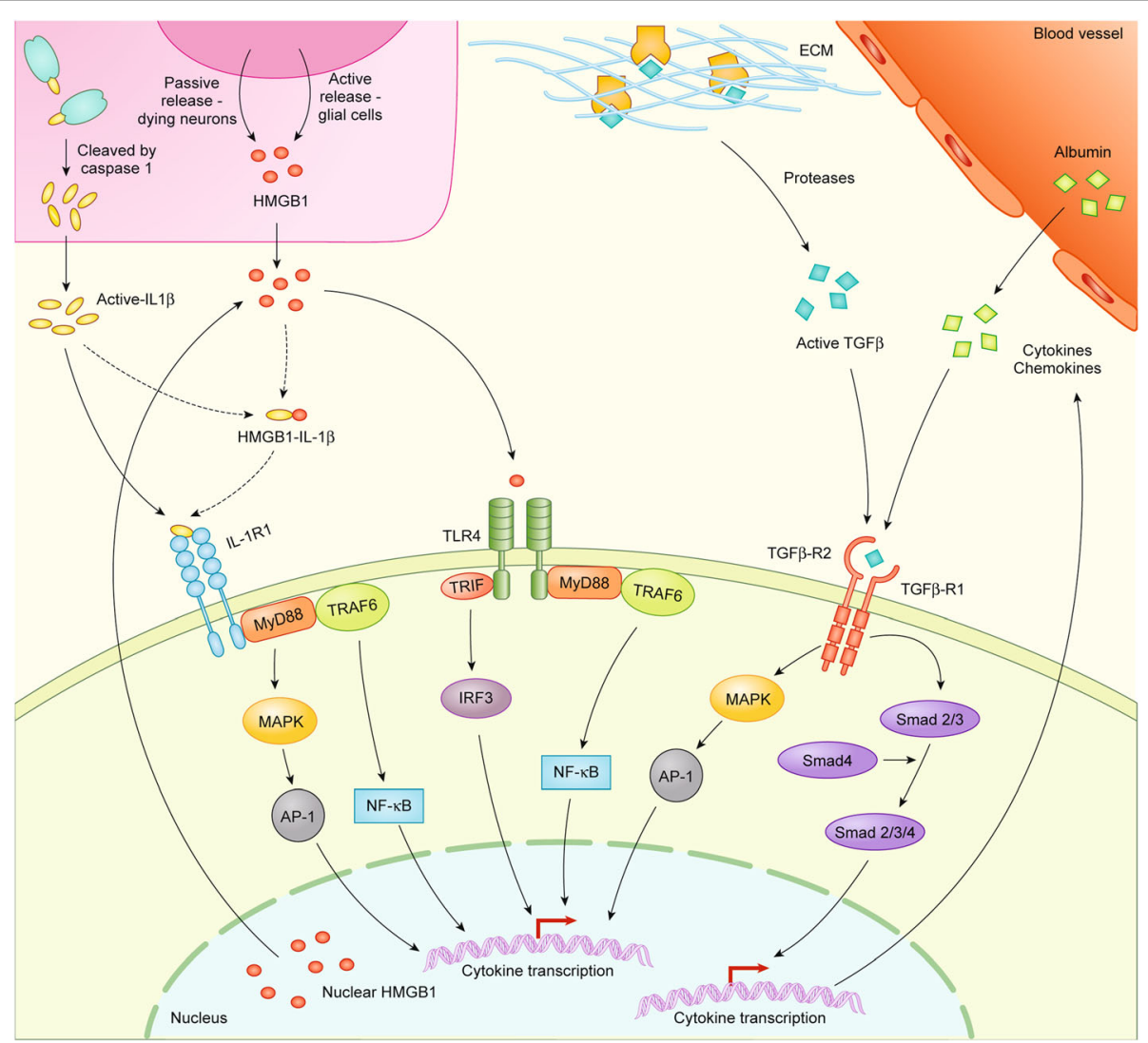

Fig. 2 Summary of three key signaling cascades that may mediate the link between inflammation and epileptogenesis. HMGB1, IL-1 $\beta$, TGF- $\beta$, and serum albumin have varied release mechanisms from multiple cell types in order to activate their signaling pathways. After injury, HMGB1 may be passively released from necrotic neurons to the extracellular space, or released actively from activated microglia and astrocytes. HMGB1 can bind to multiple receptors on many different cell types, such as TLR4, which can activate MyD88 independent pathways such as the phosphorylation of interferon regulatory transcription factor 3 (IRF3) leading to the transcription and release of interferons- $\alpha$ and - $\beta$, as well as other interferon-induced genes. HMGB1-TLR4 can also activate NF-KB signaling both directly or via TNF receptor-associated factor 6 (TRAF6). This can lead to a rapid nuclear transcription of various immune-related processes, as reviewed elsewhere [250]. Caspase-1 mediates cleavage of inactive pro-IL-1 1 to active IL-1 $\beta$, allowing for its relocation into the extracellular space, where IL-1 $\beta$ can bind to IL-1R1 either directly or in complex with HMGB1. The IL-1 $/$ /L-1R1 complex can then induce NF-KB signaling via TRAF6 or activate MyD88-dependent MAPK signaling, which has been linked to the production of various neurotoxic molecules. TGF- $\beta$ is released in an inactive form from cells and binds to the extracellular matrix. Proteases, released after injury, cleave the inactive protein to active TGF- $\beta$, which is able to bind to the two TGF- $\beta$ receptors. Mechanical breakdown of the BBB allows serum albumin into the extracellular space, where it can also bind to TGF- $\beta$ receptor1 and receptor2, which signal via Smad complex proteins or MAPK signaling pathways, respectively, to regulate the immune response. This pathway has also been implicated in post-translational changes to a variety of voltage-dependent ion channels implicated in changes to neuronal excitability [94] 
There are several lines of evidence implicating IL-1 $\beta$ in the development of PTE. Firstly, IL-1 $\beta$ is rapidly and highly upregulated following experimental and clinical TBI. In rodent models, Il-1 $\beta$ expression is upregulated as early as $1 \mathrm{~h}$ post-TBI $[121,122]$ and peaks between 12 and $24 \mathrm{~h}[54,123,124]$. This response may then persist for several months post-injury [125]. Consistent with experimental findings, analysis of protein, and gene expression in post-mortem brain tissue from TBI patients found that IL-1 $\beta$ was upregulated in individuals who died $6-122 \mathrm{~h}$ post-injury [126]. This is consistent with reports of elevated IL- $1 \beta$ in the CSF and serum of severe TBI patients $[127,128]$, correlated with poor outcomes in both children and adults $[19,129]$. Thus IL-1 $\beta$ levels are elevated during the period of secondary injury after TBI, which has been postulated to also be an important time period for the epileptogenic process [130]. Notably, numerous studies indicate that modulating IL- $1 \beta$ signaling is broadly beneficial in experimental TBI models. Treatment with an IL-1 $\beta$ neutralizing antibody alleviated TBI-induced microglial activation, neutrophil infiltration, cerebral edema, and cognitive deficits in mouse models of TBI [131, 132]. In line with this finding, IL1R1 deficient mice also showed decreased cerebral edema and leukocyte infiltration following TBI [133], and post-injury administration of an IL-1R1 antagonist attenuated neuronal cell death and cognitive dysfunction in rats [134]. A phase II clinical trial employing an IL-1R antagonist treatment $(100 \mathrm{mg} /$ day subcutaneously administered for 5 days) was recently conducted in patients with severe diffuse TBI, demonstrating safety penetration into the plasma and brain extracellular fluid, and an alteration of the immune profile [135].

One of the key clinical studies linking IL-1 $\beta$ with PTE was conducted by Diamond and colleagues, who examined whether genetic variation in the IL-1 $\beta$ gene and CSF/serum IL-1 $\beta$ ratios correlated with PTE development in a cohort of 256 patients with moderate to severe TBI [136]. Serum and CSF were collected from a portion of subjects within the first week post-injury, and IL-1 $\beta$ levels were assessed in relation to the later incidence of PTE. Further, IL-1 $\beta$ tagging and functional single nucleotide polymorphisms (SNPs) were genotyped to evaluate its association to PTE. Elevated CSF/serum IL- $1 \beta$ ratios were found to be associated with increased risk of PTE, and one of IL- $1 \beta$ SNPs, rs1143634, showed an association between the heterozygote genotype and increased PTE risk [136]. Further research is required to determine the contribution of genetic variability to IL- $1 \beta$ function and how this may influence the inflammatory response after TBI.

IL-1 $\beta$ has also been linked to other epilepsies in addition to PTE. For example, IL-1 $\beta$ may play a role in epileptogenesis that follows FS. Specifically, IL-1 $\beta$ levels were found to be acutely upregulated in rats after prolonged FS, and IL-1 $1 \beta$ levels remained elevated only in rats that developed spontaneous limbic seizures after prolonged FS [137]. In another study, IL-1R1 deficient mice were found to be resistant to experimental FS [138].

There are a number of possible mechanisms by which IL- $1 \beta$ may contribute to PTE. IL-1 $\beta$ can modulate neuronal hyperexcitability through $\mathrm{Ca}^{2+}$, glutamatergic, and GABAergic pathways [139]. By acting on glia cells, IL-1 $\beta$ mediates astrocytes and microglia activation, formation of a glial scar, and the release of neurotoxic mediators to promote cell loss, features which are associated with epileptic foci in the brain [140]. Furthermore, IL-1 $\beta$ signaling may promote epileptogenesis by enhancing BBB permeability and enhancing the recruitment of peripheral leukocytes into the brain [141-144]. There are many proposed mechanisms of IL-1 $\beta$ signaling in areas that are still poorly understood, and future research into these may reveal the way in which they interact to increase the risk of epileptogenesis.

Although less commonly studied, other members of the IL-1 family have also been investigated in the context of TBI and epilepsy. For example, an upregulation of IL- $1 \alpha$ has been reported in brain tissue following experimental TBI $[145,146]$. In the clinical setting, peripheral blood mononuclear cells collected from epilepsy patients exhibited greater production of IL- $1 \alpha$ in response to stimulation in vitro compared to cells from non-epileptic controls [147]. However, no association has been found between gene polymorphisms of IL- $1 \alpha$ and TBI outcomes [148], nor IL- $1 \alpha$ and seizure pathogenesis [149]. Taken together, there is much accumulating experimental and clinical evidence implicating IL-1 cytokines in epileptogenesis, however further studies are needed to delineate their precise roles and whether therapeutically targeting them can mitigate PTE.

\section{HMGB1/TLR4 signaling in PTE}

HMGB1 was originally identified as a ubiquitous, highly evolutionarily conserved, chromatin-binding protein, most often found in the cell nucleus of healthy tissues [150-152]. Discovered in 1973, and named due to its ability to migrate quickly during gel electrophoresis [153], HMGB1 participates in the formation of nucleosomes and is important in the regulation of gene transcription [151, 154, 155]. More recently, HMGB1 has been identified as a damage-associated molecular pattern (DAMP) [150], which are molecules that are able to initiate or perpetuate inflammation. Complete gene deficiency of HMGB1 is lethal during early postnatal life, indicating its essential role in transcriptional control [156]. A 98\% homology between human HMGB1 and mouse HMGB1 enables clinically relevant experimental investigation through animal models [157]. 
HMGB1 has two modes of cellular release in injured tissue. Immediately after injury, necrosis allows a passive release of significant amounts of HMGB1 from the nucleus into the extracellular space [158]. HMGB1 may undergo post-translational oxidation and acetylation, resulting in its active release by immune cells in response to various cytokines including itself, allowing a powerful positive feedback loop during inflammation [157, 159-161]. In addition, HMGB1 may be released upon activation by a wide range of cells in the CNS including neurons, microglia, macrophages, monocytes, natural killer cells, dendritic cells, ECs, and platelets [162].

High levels of HMGB1 have been found in epileptogenic tissue resected during surgery $[83,163]$, implicating a role for this DAMP in neuronal hyperexcitability. Experimental evidence from an animal model of temporal lobe epilepsy suggests that HMGB1 contributes to seizure activity and epilepsy [164]. One previous study by Maroso and colleagues demonstrated that intracerebral injection of HMGB1 in wild type mice increased seizure activity in response to a stimulus [165]. This pro-convulsant effect of HMGB1 is most likely mediated through one of its key signaling receptors, TLR4, as a comparable increase in seizure susceptibility was not seen in non-functional TLR4 mutant mice [165]. TLR4 mutant mice were also found to be intrinsically resistant to seizures as compared to wild type mice [165]. Interfering with the binding of HMGB1 to TLR4 has been shown to reduce both seizure frequency and onset. For example, TLR4 antagonists and BoxA, a competitive antagonist to HMGB1 comprising of the BoxA domain of the protein, have been reported to reduce and even inhibit epileptic activity that is resistant to standard ASDs in an animal model of temporal lobe epilepsy [166].

In another recent study, the mechanism by which HMGB1 signaling promotes neuronal hyperexcitability and seizure activity was found to be through an increase in NMDA receptor function in TLR4-expressing hippocampal neurons [167]. This effect was dependent on the oxidation of HMGB1 characteristic of its active release from immune cells, and was associated with high levels of NMDA-induced excitotoxic cell death [167]. Because the inflammatory environment after TBI involves the rapid production of ROS and free radicals [168, 169], there is a physiological preference towards the extracellular oxidation of HMGB1, thus increasing TLR4mediated augmentation of NMDA functionality and promoting seizure susceptibility [167].

Downstream of HMGB1, TLR4 mRNA expression is upregulated in response to brain insult [170], consistent with upregulation of this receptor during seizure activity in experimental models of epilepsy [165]. TLR4 is able to transmit signals via both myeloid differentiation primary response gene 88 (MyD88) dependent and independent pathways [171]. It is through the MyD88 dependent pathway that TLR4 is able to activate NF- $\kappa B$, which may be responsible for increasing pro-inflammatory cytokine expression to augment the inflammatory response [172, 173]. This pathway has generated great interest recently, and with the potential to modulate epileptic activity, even in drug-resistant epilepsy, further research is needed to confirm the potential of this pathway as a target for therapeutic intervention in the development of PTE.

Previous research has also suggested that HMGB1 is able to enhance inflammation through forming a complex with different cytokines, including IL-1 $\beta$ [174]. HMGB1 bound to IL-1 $\beta$ has been isolated from cell cultures when co-incubated [174]. Studies of joint inflammation in animals have also shown that when HMGB1 is present with IL- $1 \beta$ there is an enhanced inflammatory response, most likely through action on with IL-1 receptor 1[175], Whilst this complex has yet to be identified in brain tissue, further research is needed into this pathway as it may play a vital role in extending a bias towards epileptogenesis.

By contributing to acute and chronic seizures, both directly and indirectly, the HMGB1-TLR4 axis is therefore a promising target for TLEs that are resistant to ASDs $[165,167]$. This is important in the context of TBI, as seizure pathology can begin as early as the day of a brain injury [176]. Together, these data support a key role for HMGB1 in neuronal hyperexcitability and implicate the HMGB1-TLR4 signaling pathway as a potential therapeutic target to modulate post-traumatic epileptogenesis.

\section{TGF- $\beta$ /albumin involvement in PTE}

Vascular dysfunction has been associated with many types of focal and acquired epilepsies, including PTE [177]. BBB dysfunction is also a common feature of TBI in both patients and experimental models [6, 178]. Vascular dysfunction after TBI, in particular the localized breakdown of the $\mathrm{BBB}$ surrounding focal regions of tissue damage, is hypothesized to trigger a series of epileptogenic processes [179]. For example, increased permeability of the $\mathrm{BBB}$ is evident by magnetic resonance imaging with gadolinium and co-localized with the focal epileptogenic region in patients with PTE $[180,181]$.

A proposed mechanism of BBB breakdown in this context is through the TGF- $\beta$ /albumin-mediated signaling pathway. In the laboratory, experimental opening of the $\mathrm{BBB}$ in the rodent neocortex was found to trigger epileptogenesis, which was recapitulated by exposure of the brain to serum albumin [182]. Albumin has been shown to induce the production of excitatory synapses experimentally both in vitro and in vivo [183]. Serum albumin in the rodent brain has been shown to result in 
hypersynchronized responses to electrical stimulation [184], analogous to those observed in animal models of epilepsy $[185,186]$. The formation of epileptiform activity after albumin exposure is delayed, suggesting that the mechanism of action is complex rather than a direct effect by albumin [184]. One possible mechanism which has been receiving scrutiny is the activation of astrocytes by serum albumin [109, 187], activating a TGF- $\beta$ receptor-mediated signaling cascade [64, 182, 184].

TGF- $\beta$ is a pleiotropic cytokine involved in various cellular processes, including cell growth, differentiation, morphogenesis, apoptosis, and immune responses through intercellular communication in many different cell types [188-190]. Signaling is mediated by binding of TGF- $\beta$ to two serine threonine kinase receptors, which when activated cause the phosphorylation of the Smad protein complex and the p38 MAPK pathway [191]. A role for TGF- $\beta$ has been implicated in many different CNS diseases, related to its upregulation in Alzheimer's disease, multiple sclerosis, ischemic brain injury, and TBI [192]. TGF- $\beta$ is thought to have neuroprotective properties, and is associated with both microglial activation and the wound healing response [193]. Paradoxically, TGF- $\beta$ also appears to contribute to excitotoxicity, adding to the dual role of inflammation which is dependent on the context and cell types involved [194]. Further research into the variation in response from this pathway is needed, as this may reveal insights into the dual role of inflammation and how to bias the brain towards neuroprotection rather than neurodegeneration.

The binding of albumin to TGF- $\beta$ receptor has been characterized experimentally in rodent models of $\mathrm{BBB}$ disruption, resulting in the activation of TGF- $\beta$ signaling [184]. The induction of experimental BBB dysfunction to induce epileptiform activity can be prevented through blockage of albumin binding to TGF- $\beta$ receptors [184]. Much of the published literature has focused on albumin's interaction with the TGF- $\beta$ signaling pathway in disease models, but there is some suggestion that TGF- $\beta$ may also play a role in PTE from animal models with similar pathologies. In rodent models of epilepsy, TGF- $\beta$ is reportedly upregulated in both neurons [195] and hippocampal astrocytes [196]. The action of TGF- $\beta$ in astrocytes following exposure to albumin has also been shown to induce pro-ictogenic cytokine production, resulting in increased neuronal excitability in experimental models [197]. TGF- $\beta$ has also been implicated experimentally in excitatory synaptogenesis in a post-injury epilepsy model [183]. As neuronal reorganization and synaptogenesis are hypothesized to be a potential mechanism underlying chronic seizures and are well-documented consequences of CNS trauma, this action of TGF- $\beta$ may be critical for the progression of brain injury to epilepsy [183, 198, 199]. In summary, the actions of TGF- $\beta$ in the injured and epileptic brain remain poorly understood, but the potentially paradoxical behavior of this cytokine warrants further investigation.

\section{Age-specific vulnerability to PTE}

Neuroinflammation is a key aspect of secondary injury that can vary according to the stage of brain development, which may underlie differences in clinical outcomes between patients who suffer a TBI during childhood and patients who suffer a TBI during adulthood [200]. Many studies now suggest that the early postnatal brain has an enhanced propensity for inflammation, described as a 'window of susceptibility' [200-202]. Early support for this hypothesis came from experimental evidence that 3-week old (juvenile) rats showed a higher susceptibility to IL-1 $\beta$-induced BBB breakdown compared to adult rats [203, 204]. These observations are most likely not due to an immaturity of the $\mathrm{BBB}$ integrity at a younger age, as the tight junctions that maintain the $\mathrm{BBB}$ are fully developed from prenatal stages [205], but rather to a unique global chemokine expression profile that is distinctly different to the adult CNS [200]. In experimental autoimmune encephalomyelitis, a model of multiple sclerosis that shares some of the inflammatory processes of PTE, many chemokines involved in the recruitment of $\mathrm{T}$ cells and monocytes into the brain are robustly upregulated to 2-6-fold higher in juveniles compared to adults, including CCL2, CCL3, and CCL6 [200, 206-208]. There is also some evidence in the clinical context that the response of the immune system in the brain after a pathogenic challenge also differs between adults and children, with children presenting with higher production of IL-1 and IL-10 from peripheral blood monocytes after pathogenic stimulation [209]. Several cytokines have been detected at elevated levels in both CSF and serum of children after TBI, including IL-1 $\alpha$, IL-6, IL-12, and TNF- $\alpha$, though how this response may correspond to the clinical differences at different ages after TBI are still relatively underinvestigated [210-212].

Microglia present differently within the immature brain compared to adults. During early postnatal development, their morphology is distinct, with fewer processes than those in the adult brain [213], and in an experimental pathogenic model, neonatal brain injury induced a markedly reduced activation compared to the robust activation seen in adult brain tissue [214]. Activated microglia typically adopt a phagocytic morphology and are associated with neuronal death, which is thought to be a critical aspect of normal brain development [201, 215]. There are also more circulating macrophages in the developing brain compared to adults under basal conditions associated with dying neurons 
and glia, particularly in the corpus callosum [213, 216]. Neutrophil infiltration into brain parenchyma after injury differs across ages, with a much higher level of infiltration detected experimentally in postnatal day 7 (p7) rats than in adults [214]. This neutrophil infiltration can persist 2-3 days after a pathogenic challenge and was found to be concurrent with damage to vasculature $[203,204,214]$.

Increased seizure susceptibility in the immature brain may result from several contributing factors. Glutamate is the primary neurotransmitter in both the adult and developing brain [217], yet there is low expression of the glutamate type 1 transporter, therefore, clearance from the synaptic cleft is markedly slower compared that in the adult brain [218]. GABA receptor action is normally inhibitory in the adult brain, but is predominantly excitatory during early brain development due to high intracellular concentrations of chloride as a result of differential developmental expression of specific chloride ion transporters [219-221]. During early cortical development, experimental models have shown that GABA is predominantly depolarizing, progressing through childhood to the hyperpolarizing state found in the healthy adult brain [222, 223]. A recent study of experimental mesial temporal lobe epilepsy found a depolarizing role of GABA receptor, which was highly upregulated in surviving epileptic neurons [224], suggesting that the early neurodevelopmental environment may be more vulnerable to hyperexcitability after an insult. NMDA receptors are also more permeable to $\mathrm{Ca}^{2+}$ during development and desensitize more slowly [225]. In addition to a shorter post-ictal refractory period compared to the adult brain [226, 227], this inherently increased excitability of the pediatric brain may underlie an increased propensity for PTE after TBI during early childhood.

However, other studies have noted that the immature brain may conversely show resistance to seizure-related pathology; for example, chemical stimulation to experimentally induce sustained hyperexcitability is more difficult in the immature brain [39]. Infant brains may also be more resistant to excitotoxic-induced cell death than the adult brain [228]. Due to the apparent paradox of age-related differences, further study pertaining to the specific excitability of the developing environment is needed, particularly in the context of brain injury.

\section{Inflammation in pediatric PTE}

As a result of the abovementioned evidence of agespecific responses to both inflammatory stimuli and seizures, a potential link between neuroinflammation and seizure susceptibility particularly during early childhood is under intense scrutiny. Experimental studies have implicated a role for neuroinflammation in increased seizure susceptibility in the immature brain; for example, exposure to several chemoconvulsant challenges revealed a lower seizure threshold in immature rats compared to adults [102]. The authors attribute this response to increased TNF- $\alpha$ or IL- $1 \beta$ production by activated microglia in the hippocampus in immature rats, which was associated with cognitive deficits and widespread neuronal loss [102, 229]. Changes in seizure threshold caused by neuroinflammation in the pediatric brain are associated with long-term alterations in glutamate receptors in the hippocampus, and a resultant increase in neuronal network excitability $[229,230]$.

In addition to the younger brain having an increased propensity for an enhanced neuroinflammatory response, age-specific differences in important epileptogenic factors have been identified. One such difference is NMDA receptor density, which has been shown experimentally to peak at p28 at approximately $160 \%$ of adult levels [231]. NMDA receptors also have a different subunit composition in the developing brain compared to the adult brain, resulting in different functional properties [232, 233]. Due to these changes, NMDA receptors are able to depolarize more easily in the presence of glutamate, resulting in a longer duration of excitatory postsynaptic currents $[218,234]$.

\section{Therapeutic targeting of post-traumatic inflamma- tion to prevent PTE}

TBI induces a neuroinflammatory cascade in the brain, leading to persistent and perpetuating neurodegeneration and likely contributing to an increased risk of initiating epileptogenesis, resulting in the development of PTE. In the context of the ongoing pursuit of novel therapeutic targets to prevent PTE, both clinical and experimental studies provide compelling evidence implicating IL-1 $\beta$ and HMGB1 as pivotal players in the cascade. Due to their early and varied role in the neuroinflammatory cascade after injury and emerging roles in the regulation of neuronal excitability, pharmacological targeting of these mechanisms may prove beneficial at reducing PTE. Further pre-clinical studies are needed to elucidate the exact mechanisms by which these and other inflammatory mediators initiate or perpetuate the process of epileptogenesis.

Several different animal models of PTE have been well studied over the past decade [235]. These experimental models have demonstrated that TBI results in both acute and chronic changes to the neuronal environment that likely contribute to epileptogenesis, such as hyperexcitable recurrent circuitry in the dentate gyrus of the hippocampus [235-237]. Whilst these models allow for the investigation of various mechanisms and testing of potential therapeutics, rodent models of PTE are not without limitations. Some models can produce a high level of epileptiform activity when measured with 
electroencephalogram, but most models are limited in the amount of spontaneous seizure activity they induce, leading to the need for higher animal numbers [11, 238]. One study that used a controlled cortical impact model of PTE, found that only $20-36 \%$ of animals given a severe TBI developed spontaneous behavioral seizures [239]. Though this presents logistical challenges, this incidence is only slightly higher than the estimated incidence in the clinical setting, which one study found to be $16.7 \%$ for severe TBI [240]. Animal models are also notoriously time-consuming as the latency to spontaneous seizure onset can be weeks to months after the initial injury [238, 241]. To increase the number of animals that can be investigated in relation to epileptogenesis and combat time restraints, some studies incorporate the administration of a pro-convulsant agent, such as pentylenetetrazol (PTZ), to unveil changes to seizure threshold as a surrogate marker of seizure susceptibility [235, 238, 241]. Many neuropathological processes that occur following TBI, including the neuroinflammatory response, can also differ greatly due to the developmental state of the brain at the time of impact [1]. This confound should be taken into account when investigating both the underlying mechanisms of epileptogenesis and piloting novel therapeutic interventions. Despite these limitations, these models show high clinical relevance and are useful tools with which to study PTE, and they are continually being improved upon.

Much investigation of neuroinflammatory intervention as a therapeutic option after TBI has focused on broadtarget agents, such as minocycline, erythropoietin, and progesterone. All of these treatments were proposed to reduce neuroinflammation after TBI, generating promising results in pre-clinical research but failing to produce short-term improvement after TBI during clinical trials, as reviewed elsewhere [242]. However, these treatments, which are both pleiotropic in nature and relatively safe for long-term use, may have more success in relation to the chronic outcomes such as PTE as many of the effects of neuroinflammation persist long after the offending insult, yet few studies have considered the potential effects of anti-inflammatory treatments on long-term epileptogenesis after injury. Hypothermia is another broad-target treatment for neuroinflammation that has had some success in providing neuroprotection in the context of TBI and spinal cord injuries, with some evidence suggesting that it may also prevent epileptogenesis [243-245]. The potential to prevent or reduce PTE by targeting other inflammatory mediators in the post-injury neural environment, such as serum albumin and TGF- $\beta$, have not yet been explored. Additional potential targets include TNF- $\alpha$, which has been shown to influence neurotransmission by altering excitatory post-synaptic currents and decreasing GABA-mediated inhibitory synaptic strength in hippocampal neurons [246]; the prostaglandin receptor EP2, which mediates COX-2 inflammatory signaling and appears to promote seizures by aggravating neuronal injury [247]; as well as factors involved in regeneration and regrowth such as fibroblast growth factor, tropomyosin receptor kinase B, and insulin-like growth factor-1. [248, 249]

\section{Conclusion}

This review of the published literature has found that several inflammatory mediators, including IL-1 $\beta$ and HMGB1, exhibit epileptogenic and ictogenic properties, acting on glia and neurons both directly and indirectly to influence neuronal excitability. As neuroinflammation is a central component of the neuropathology after TBI, comparable mechanisms are likely to be involved in the process of epileptogenesis leading to PTE. An increased understanding of how inflammation influences epileptogenesis may reveal novel therapeutic targets and strategies to prevent or reduce seizures after TBI. As PTE is often resistant to existing pharmaceutical treatments $[33,34,36]$, there is an urgent need for further research to develop preventative treatments to improve both the quality and longevity of life for TBI survivors.

\section{Abbreviations}

ASDs: Anti-seizure drugs; AMPA: Alpha-amino-3-hydroxy-5-methyl-4isoxazole-propoinate; BBB: Blood-brain barrier; CA3: Region III of hippocampus proper; CCL2: Chemokine (C-C Motif) ligand 2; CCL3: Chemokine (C-C Motif) ligand 3; CCL6: Chemokine (C-C Motif) ligand 6; CNS: Central nervous system; COX-2: Cyclooxygenase-2; CSF: Cerebrospinal fluid; CXCL8: Chemokine (C-X-C motif) ligand 8; DAMP: Damage associated molecular pattern; EC: Endothelial cells; EP2: Receptor for prostaglandin E2; FS: Febrile seizures; GABA: $\gamma$-aminobutyric acid; HMGB1: High mobility group box 1 protein; IL-1R: IL-1 receptor; IL-1R1: Cell surface type 1 IL-1 receptor;

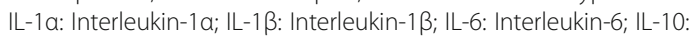
Interleukin-10; IL-12: Interleukin-12; IRF3: Interferon regulatory transcription factor 3; MAPK: Mitogen-activated protein kinase; MyD88: Myeloid differentiation primary response gene 88; NF-kB: Nuclear factor Kappa-lightchain-enhancer of activated B cells; NMDA: N-methyl-d-aspartate; p7: Postnatal day 7; p28: Postnatal day 28; PTE: Post-traumatic epilepsy; PTZ: Pentylenetetrazol; ROS: Reactive oxygen species; SNPs: Single nucleotide polymorphisms; TBI: Traumatic brain injury; TGF- $\beta$ : Transforming growth factor- $\beta$; TLE: Temporal lobe epilepsy; TLR: Toll-like receptor; TNF-a: Tumor necrosis factor- $a$; TRAF6: TNF receptor associated factor 6

\section{Acknowledgements}

Figures were prepared by Elsevier Illustration Services.

\section{Funding}

BDS and SRS are supported by fellowships from the National Health and Medical Research Council of Australia. This manuscript was written with support from the Rebecca $L$ Cooper Medical Research Foundation.

\section{Availability of data and materials}

Data sharing not applicable to this article as no datasets were generated or analyzed during the current study.

Authors' contributions

KMW and BDS conceptualized and designed the manuscript; KMW, MS, and BDS drafted the manuscript; PC, TJO'B, and SRS provided critical revisions and intellectual input. All authors read and approved the final manuscript. 


\section{Competing interests}

The authors declare that they have no competing interests.

\section{Consent for publication}

Not Applicable.

\section{Ethics approval and consent to participate}

Not applicable.

\section{Author details}

'Department of Medicine (The Royal Melbourne Hospital), The University of Melbourne, Kenneth Myer Building, Melbourne Brain Centre, Royal Parade, Parkville, VIC 3050, Australia. ${ }^{2}$ Department of Pharmacology and Therapeutics, The University of Melbourne, Parkville, VIC 3050, Australia.

\section{Received: 3 October 2016 Accepted: 28 December 2016}

\section{Published online: 13 January 2017}

\section{References}

1. Potts MB, Koh S-E, Whetstone WD, Walker BA, Yoneyama T, Claus CP, et al. Traumatic injury to the immature brain: inflammation, oxidative injury, and iron-mediated damage as potential therapeutic targets. NeuroRx. 2006;3(2): 143-53.

2. Thurman DJ. The epidemiology of traumatic brain injury in children and youths: a review of research since 1990. J Child Neurol. 2016;31(1):20-7.

3. Maas AIR, Stocchetti N, Bullock R. Moderate and severe traumatic brain injury in adults. Lancet Neurol. 2008;7(8):728-41.

4. Khoshyomn S, Tranmer BI. Diagnosis and management of pediatric closed head injury. Semin Pediatr Surg. 2004;13(2):80-6.

5. Schouten JW. Neuroprotection in traumatic brain injury: a complex struggle against the biology of nature. Curr Opin Crit Care. 2007;13(2):134-42.

6. Hinson HE, Rowell S, Schreiber M. Clinical evidence of inflammation driving secondary brain injury: a systematic review. J Trauma Acute Care Surg. 2015;78(1):184-91.

7. Dashnaw ML, Petraglia AL, Bailes JE. An overview of the basic science of concussion and subconcussion: where we are and where we are going. Neurosurg Focus. 2012:33(6):1-9.

8. Prins ML, Hovda DA. Developing experimental models to address traumatic brain injury in children. J Neurotrauma. 2003;20(2):123-37.

9. Blennow K, Hardy J, Zetterberg $H$. The neuropathology and neurobiology of traumatic brain injury. Neuron. 2012;76(5):886-99.

10. Appleton RE, Demellweek C. Post-traumatic epilepsy in children requiring inpatient rehabilitation following head injury. J Neurol Neurosurg Psychiatry 2002;72(5):669-72

11. Statler KD, Scheerlinck P, Pouliot W, Hamilton M, White HS, Dudek FE. A potential model of pediatric posttraumatic epilepsy. Epilepsy Res. 2009;86(2-3):221-3

12. Frey LC. Epidemiology of posttraumatic epilepsy: a critical review. Epilepsia. 2003:44:11-7.

13. Fisher RS, Boas WV, Blume W, Elger C, Genton P, Lee $P$, et al. Epileptic seizures and epilepsy: definitions proposed by the International League against Epilepsy (ILAE) and the International Bureau for Epilepsy (IBE). Epilepsia. 2005:46(4):470-2.

14. Pitkanen A, Immonen R. Epilepsy related to traumatic brain injury. Neurotherapeutics. 2014;11(2):286-96.

15. DeLorenzo RJ, Sun DA, Deshpande LS. Cellular mechanisms underlying acquired epilepsy: the calcium hypothesis of the induction and maintenance of epilepsy (vol 105, pg 229, 2005). Pharmacol Ther. 2006:111(1):287-325.

16. Goldberg EM, Coulter DA. Mechanisms of epileptogenesis: a convergence on neural circuit dysfunction. Nat Rev Neurosci. 2013;14(5):337-49.

17. Temkin NR. Preventing and treating posttraumatic seizures: the human experience. Epilepsia. 2009;50:10-3.

18. Walker MC, White HS, Sander J. Disease modification in partial epilepsy. Brain. 2002;125:1937-50.

19. Chiaretti A, De Benedictis R, Polidori G, Piastra M, lannelli A, Di Rocco C. Early post-traumatic seizures in children with head injury. Childs Nerv Syst. 2000;16(12):862-6.

20. Barlow KM, Spowart JJ, Minns RA. Early posttraumatic seizures in nonaccidental head injury: relation to outcome. Dev Med Child Neurol. 2000;42(9):591-4.
21. Hahn YS, Fuchs S, Flannery AM, Barthel MJ, McLone DG. Factors influencing posttraumatic seizures in children. Neurosurgery. 1988:22(5):864-7.

22. Jennett B. Trauma as a cause of epilepsy in childhood. Dev Med Child Neurol. 1973;15(1):56-62

23. Desai BT, Whitman S, Coonleyhoganson R, Coleman TE, Gabriel G, Dell J. Seizures and civilian head-injuries. Epilepsia. 1983;24(3):289-96.

24. Li H, McDonald W, Parada I, Faria L, Graber K, Takahashi DK, et al. Targets for preventing epilepsy following cortical injury. Neurosci Lett. 2011:497(3):172-6.

25. Santhakumar V, Ratzliff ADH, Jeng J, Toth Z, Soltesz I. Long-term hyperexcitability in the hippocampus after experimental head trauma. Ann Neurol. 2001;50(6):708-17.

26. Cantu D, Walker K, Andresen L, Taylor-Weiner A, Hampton D, Tesco G, et al. Traumatic brain injury increases cortical glutamate network activity by compromising GABAergic control. Cereb Cortex. 2015;25(8):2306-20.

27. Santhakumar V, Bender R, Frotscher M, Ross ST, Hollrigel GS, Toth Z, et al. Granule cell hyperexcitability in the early post-traumatic rat dentate gyrus: the 'irritable mossy cell' hypothesis. J Physiol London. 2000;524(1):117-34.

28. Santhakumar V, Aradi I, Soltesz I. Role of mossy fiber sprouting and mossy cell loss in hyperexcitability: a network model of the dentate gyrus incorporating cell types and axonal topography. J Neurophysiol. 2005;93(1):437-53.

29. Lowenstein DH, Thomas MJ, Smith DH, Mclntosh TK. Selective vulnerability of dentate hilar neurons following traumatic brain injury - a potential mechanistic link between head trauma and disorders of the hippocampus. Neurology. 1992;42(7):1427

30. Diaz-Arrastia R, Agostini MA, Frol AB, Mickey B, Fleckenstein J, Van Ness PC. Neurophysiologic and neuroradiologic features of intractable epilepsy after traumatic brain injury in adults. Arch Neurol. 2000;57(11):1611-6.

31. Hudak AM, Trivedi K, Harper CR, Booker K, Caesar RR, Agostini M, et al. Evaluation of seizure-like episodes in survivors of moderate and severe traumatic brain injury. J Head Trauma Rehab. 2004;19(4):290-5.

32. Yang L, Afroz S, Michelson HB, Goodman JH, Valsamis HA, Ling DSF. Spontaneous epileptiform activity in rat neocortex after controlled cortical impact Injury. J Neurotrauma. 2010;27(8):1541-8

33. Semah F, Picot MC, Adam C, Broglin D, Arzimanoglou A, Bazin B, et al. Is the underlying cause of epilepsy a major prognostic factor for recurrence? Neurology. 1998;51(5):1256-62.

34. Larkin M, Meyer RM, Szuflita NS, Severson MA, Levine ZT. Post-traumatic drug-resistant epilepsy and review of seizure control outcomes from blinded, randomized controlled trials of brain stimulation treatments for drug-resistant epilepsy. Cureus. 2016;8(8):e744

35. Temkin NR. Antiepileptogenesis and seizure prevention trials with antiepileptic drugs: meta-analysis of controlled trials. Epilepsia. 2001;42(4):515-24.

36. Beghi E. Overview of studies to prevent posttraumatic epilepsy. Epilepsia. 2003;44:21-6.

37. Torbic H, Forni AA, Anger KE, Degrado JR, Greenwood BC. Use of antiepileptics for seizure prophylaxis after traumatic brain injury. Am J Health Syst Pharm. 2013:70(9):759-66.

38. Kirmani BF, Robinson DM, Fonkem E, Graf K, Huang JH. Role of anticonvulsants in the management of posttraumatic epilepsy. Front Neurol. 2016;7:32

39. Kubova H, Mares P, Suchomelova L, Brozek G, Druga R, Pitkanen A. Status epilepticus in immature rats leads to behavioural and cognitive impairment and epileptogenesis. Eur J Neurosci. 2004:19(12):3255-65.

40. Statler KD. Pediatric posttraumatic seizures: epidemiology, putative mechanisms of epileptogenesis and promising investigational progress. Dev Neurosci. 2006;28(4-5):354-63.

41. Hickey WF. Basic principles of immunological surveillance of the normal central nervous system. Glia. 2001;36(2):118-24.

42. Auffray C, Sieweke MH, Geissmann F. Blood monocytes: development, heterogeneity, and relationship with dendritic cells. Annu Rev Immunol. 2009:27:669-92.

43. Cederberg D, Siesjo P. What has inflammation to do with traumatic brain injury? Childs Nerv Syst. 2010;26(2):221-6.

44. DeKosky ST, Blennow K, Ikonomovic MD, Gandy S. Acute and chronic traumatic encephalopathies: pathogenesis and biomarkers. Nat Rev Neurol. 2013:9(4):192-200

45. Riazi K, Galic MA, Pittman QJ. Contributions of peripheral inflammation to seizure susceptibility: cytokines and brain excitability. Epilepsy Res. 2010;89(1):34-42.

46. Utagawa A, Truettner JS, Dietrich WD, Bramlett HM. Systemic inflammation exacerbates behavioral and histopathological consequences of isolated traumatic brain injury in rats. Exp Neurol. 2008;211(1):283-91. 
47. Vezzani A, Granata T. Brain inflammation in epilepsy: experimental and clinical evidence. Epilepsia. 2005;46(11):1724-43.

48. Morganti-Kossmann MC, Rancan M, Stahel PF, Kossmann T. Inflammatory response in acute traumatic brain injury: a double-edged sword. Curr Opin Crit Care. 2002;8(2):101-5.

49. Hudome S, Palmer C, Roberts RL, Mauger D, Housman C, Towfighi J. The role of neutrophils in the production of hypoxic-ischemic brain injury in the neonatal rat. Pediatr Res. 1997;41(5):607-16.

50. Owen CA, Campbell EJ. The cell biology of leukocyte-mediated proteolysis. J Leukoc Biol. 1999;65(2):137-50.

51. Chodobski A, Zink BJ, Szmydynger-Chodobska J. Blood-brain barrier pathophysiology in traumatic brain injury. Transl Stroke Res. 2011;2(4):492-516.

52. Dempsey RJ, Baskaya MK, Dogan A. Attenuation of brain edema, bloodbrain barrier breakdown, and injury volume by ifenprodil, a polyamine-site $\mathrm{N}$-methyl-D-aspartate receptor antagonist, after experimental traumatic brain injury in rats. Neurosurgery. 2000:47(2):399-404.

53. Ransohoff RM, Tani M. Do chemokines mediate leukocyte recruitment in post-traumatic CNS inflammation? Trends Neurosci. 1998;21(4):154-9.

54. Semple BD, Bye N, Rancan M, Ziebell JM, Morganti-Kossmann MC. Role of CCL2 (MCP-1) in traumatic brain injury (TBI): evidence from severe TBI patients and CCL2-/- mice. J Cereb Blood Flow Metab. 2010;30(4):769-82.

55. Nonaka M, Chen XH, Pierce JES, Leoni MJ, Mclntosh TK, Wolf JA, et al. Prolonged activation of NF-kappa B following traumatic brain injury in rats. J Neurotrauma. 1999;16(11):1023-34.

56. Scherbel U, Raghupathi R, Nakamura M, Saatman KE, Trojanowski JQ, Neugebauer $E$, et al. Differential acute and chronic responses of tumor necrosis factor-deficient mice to experimental brain injury. Proc Natl Acad Sci U S A. 1999;96(15):8721-6.

57. Sherwood ER, Prough DS. Interleukin-8, neuroinflammation, and secondary brain injury. Crit Care Med. 2000;28(4):1221-3.

58. Kreutzberg GW. Microglia: a sensor for pathological events in the CNS Trends Neurosci. 1996;19(8):312-8.

59. Braughler JM, Hall ED. Central nervous system trauma and stroke. I. Biochemical considerations for oxygen radical formation and lipid peroxidation. Free Radic Biol Med. 1989;6(3):289-301.

60. Hall ED, Braughler JM. Central nervous system trauma and stroke. II. Physiological and pharmacological evidence for involvement of oxygen radicals and lipid peroxidation. Free Radic Biol Med. 1989;6(3):303-13.

61. Smith SL, Andrus PK, Zhang JR, Hall ED. Direct measurement of hydroxyl radicals, lipid peroxidation, and blood-brain barrier disruption following unilateral cortical impact head injury in the rat. J Neurotrauma. 1994;11(4):393-404.

62. Campbell IL, Abraham CR, Masliah E, Kemper P, Inglis JD, Oldstone MB, et al Neurologic disease induced in transgenic mice by cerebral overexpression of interleukin 6. Proc Natl Acad Sci U S A. 1993;90(21):10061-5.

63. Ravizza T, Balosso S, Vezzani A. Inflammation and prevention of epileptogenesis. Neurosci Lett. 2011;497(3):223-30.

64. David Y, Cacheaux LP, Ivens S, Lapilover E, Heinemann U, Kaufer D, et al. Astrocytic dysfunction in epileptogenesis: consequence of altered potassium and glutamate homeostasis? J Neurosci. 2009;29(34):10588-99.

65. Tchelingerian JL, Monge M, Lesaux F, Zalc B, Jacque C. Differential oligodendroglial expression of the tumor-necrosis-factor receptors in-vivo and in-vitro. J Neurochem. 1995;65(5):2377-80.

66. Shohami E, Ginis I, Hallenbeck JM. Dual role of tumor necrosis factor alpha in brain injury. Cytokine Growth Factor Rev. 1999;10(2):119-30.

67. Matsumoto H, Marsan CA. Cortical cellular phenomena in experimental epilepsy: ictal manifestations. Exp Neurol. 1964;9:305-26.

68. Cobb SR, Buhl EH, Halasy K, Paulsen O, Somogyi P. Synchronization of neuronal activity in hippocampus by individual GABAergic interneurons. Nature. 1995;378(6552):75-8.

69. Avoli M, de Curtis M, Gnatkovsky V, Gotman J, Kohling R, Levesque $M$, et al. Specific imbalance of excitatory/inhibitory signaling establishes seizure onset pattern in temporal lobe epilepsy. J Neurophysiol. 2016;115(6):3229-37

70. de Curtis M, Avoli M. GABAergic networks jump-start focal seizures. Epilepsia. 2016;57(5):679-87.

71. Lason W, Chlebicka M, Rejdak K. Research advances in basic mechanisms of seizures and antiepileptic drug action. Pharmacol Rep. 2013;65(4):787-801.

72. Sayyah M, Javad-Pour M, Ghazi-Khansari M. The bacterial endotoxin lipopolysaccharide enhances seizure susceptibility in mice: involvement of proinflammatory factors: nitric oxide and prostaglandins. Neuroscience. 2003;122(4):1073-80.

73. Dhote F, Peinnequin A, Carpentier P, Baille V, Delacour C, Foquin A, et al. Prolonged inflammatory gene response following soman-induced seizures in mice. Toxicology. 2007;238(2-3):166-76.

74. Levesque M, Avoli M, Bernard C. Animal models of temporal lobe epilepsy following systemic chemoconvulsant administration. J Neurosci Methods. 2016;260:45-52

75. Gorter JA, van Vliet EA, da Silva FH L. Which insights have we gained from the kindling and post-status epilepticus models? J Neurosci Methods. 2016;260:96-108.

76. De Simoni MG, Perego C, Ravizza T, Moneta D, Conti M, Marchesi F, et al. Inflammatory cytokines and related genes are induced in the rat hippocampus by limbic status epilepticus. Eur J Neurosci. 2000;12(7):2623-33.

77. Turrin NP, Rivest $\mathrm{S}$. Innate immune reaction in response to seizures: implications for the neuropathology associated with epilepsy. Neurobiol Dis. 2004;16(2):321-34

78. Gorter JA, van Vliet EA, Aronica E, Breit T, Rauwerda H, da Silva FHL, et al. Potential new antiepileptogenic targets indicated by microarray analysis in a rat model for temporal lobe epilepsy. J Neurosci. 2006;26(43):11083-110.

79. Oprica M, Eriksson C, Schultzberg M. Inflammatory mechanisms associated with brain damage induced by kainic acid with special reference to the interleukin-1 system. J Cell Mol Med. 2003;7(2):127-40.

80. Vezzani A, Conti N, De Luigi A, Ravizza T, Moneta D, Marchesi F, et al. Interleukin-I beta immunoreactivity and microglia are enhanced in the rat hippocampus by focal kainate application: functional evidence for enhancement of electrographic seizures. J Neurosci. 1999;19(12):5054-65.

81. Peltola J, Laaksonen J, Haapala AM, Hurme M, Rainesalo S, Keranen T. Indicators of inflammation after recent tonic-clonic epileptic seizures correlate with plasma interleukin-6 levels. Seizure Eur J Epilepsy. 2002;11(1):44-6.

82. Peltola J, Palmio J, Korhonen L, Suhonen J, Miettinen A, Hurme M, et al. Interleukin-6 and Interleukin-1 receptor antagonist in cerebrospinal fluid from patients with recent tonic-clonic seizures. Epilepsy Res. 2000:41(3):205-11.

83. Crespel A, Coubes P, Rousset M-C, Brana C, Rougier A, Rondouin G, et al. Inflammatory reactions in human medial temporal lobe epilepsy with hippocampal sclerosis. Brain Res. 2002;952(2):159-69.

84. Kharatishvili I, Pitkanen A. Association of the severity of cortical damage with the occurrence of spontaneous seizures and hyperexcitability in an animal model of posttraumatic epilepsy. Epilepsy Res. 2010;90(1-2):47-59.

85. Kirkman NJ, Libbey JE, Wilcox KS, White HS, Fujinami RS. Innate but not adaptive immune responses contribute to behavioral seizures following viral infection. Epilepsia. 2010;51(3):454-64.

86. Vezzani A, Balosso S, Ravizza T. The role of cytokines in the pathophysiology of epilepsy. Brain Behav Immun. 2008;22(6):797-803.

87. Lloyd E, Somera-Molina K, Van Eldik LJ, Watterson DM, Wainwright MS. Suppression of acute proinflammatory cytokine and chemokine upregulation by post-injury administration of a novel small molecule improves long-term neurologic outcome in a mouse model of traumatic brain injury. J Neuroinflammation. 2008;5:28.

88. Somera-Molina KC, Robin B, Somera CA, Anderson C, Stine C, Koh S, et al. Glial activation links early-life seizures and long-term neurologic dysfunction: evidence using a small molecule inhibitor of proinflammatory cytokine upregulation. Epilepsia. 2007;48(9):1785-800.

89. Viviani B, Gardoni F, Marinovich M. Cytokines and neuronal ion channels in health and disease. Int Rev Neurobiol. 2007:82:247-63.

90. Cunningham AJ, Murray CA, O'Neill LA, Lynch MA, O'Connor JJ. Interleukin-1 beta (IL-1 beta) and tumour necrosis factor (TNF) inhibit long-term potentiation in the rat dentate gyrus in vitro. Neurosci Lett. 1996;203(1):17-20.

91. Probert L, Akassoglou K, Pasparakis M, Kontogeorgos G, Kollias G. Spontaneous inflammatory demyelinating disease in transgenic mice showing central nervous system-specific expression of tumor necrosis factor alpha. Proc Natl Acad Sci U S A. 1995;92(24):11294-8

92. Samland H, Huitron-Resendiz S, Masliah E, Criado J, Henriksen SJ, Campbell IL. Profound increase in sensitivity to glutamatergic- but not cholinergic agonist-induced seizures in transgenic mice with astrocyte production of IL-6. J Neurosci Res. 2003;73(2):176-87.

93. Bradford HF. Glutamate, GABA and epilepsy. Prog Neurobiol. 1995;47(6):477-511.

94. Hu S, Sheng WS, Ehrlich LC, Peterson PK, Chao CC. Cytokine effects on glutamate uptake by human astrocytes. Neuroimmunomodulation. 2000;7(3):153-9. 
95. Balosso S, Ravizza T, Pierucci M, Calcagno E, Invernizzi R, Di Giovanni G, et al Molecular and functional interactions between tumor necrosis factor-alpha receptors and the glutamatergic system in the mouse hippocampus: implications for seizure susceptibility. Neuroscience. 2009;161(1):293-300.

96. Pickering M, Cumiskey D, O'Connor JJ. Actions of TNF-alpha on glutamatergic synaptic transmission in the central nervous system. Exp Physiol. 2005;90(5):663-70.

97. Godukhin OV, Levin SG, Parnyshkova EY. The effects of interleukin-10 on the development of epileptiform activity in the hippocampus induced by transient hypoxia, bicuculline, and electrical kindling. Neurosci Behav Physiol. 2009;39(7):625-31.

98. Shandra AA, Godlevsky LS, Vastyanov RS, Oleinik AA, Konovalenko VL, Rapoport EN, et al. The role of TNF-alpha in amygdala kindled rats. Neurosci Res. 2002;42(2):147-53

99. Bilbo SD, Rudy JW, Watkins LR, Maier SF. A behavioural characterization of neonatal infection-facilitated memory impairment in adult rats. Behav Brain Res. 2006;169(1):39-47.

100. Boisse L, Mouihate A, Ellis S, Pittman QJ. Long-term alterations in neuroimmune responses after neonatal exposure to lipopolysaccharide. J Neurosci. 2004;24(21):4928-34.

101. Ellis S, Mouihate A, Pittman QJ. Neonatal programming of the rat neuroimmune response: stimulus specific changes elicited by bacterial and viral mimetics. J Physiol. 2006;571(Pt 3):695-701.

102. Galic MA, Riazi K, Henderson AK, Tsutsui S, Pittman QJ. Viral-like brain inflammation during development causes increased seizure susceptibility in adult rats. Neurobiol Dis. 2009;36(2):343-51.

103. Hesdorffer DC, Shinnar S, Lax DN, Pellock JM, Nordli Jr DR, Seinfeld S, et al. Risk factors for subsequent febrile seizures in the FEBSTAT study. Epilepsia. 2016;57(7):1042-7.

104. Baulac S, Gourfinkel-An I, Nabbout R, Huberfeld G, Serratosa J, Leguern E, et al. Fever, genes, and epilepsy. Lancet Neurol. 2004;3(7):421-30.

105. Virta M, Hurme M, Helminen M. Increased frequency of interleukin-1 beta (-511) allele 2 in febrile seizures. Pediatr Neurol. 2002;26(3):192-5.

106. Hulkkonen J, Laippala P, Hurme M. A rare allele combination of the interleukin-1 gene complex is associated with high interleukin-1 beta plasma levels in healthy individuals. Eur Cytokine Netw. 2000;11(2):251-5.

107. Kanemoto K, Kawasaki J, Miyamoto T, Obayashi H, Nishimura M. Interleukin (IL)1 beta, IL-1alpha, and IL-1 receptor antagonist gene polymorphisms in patients with temporal lobe epilepsy. Ann Neurol. 2000;47(5):571-4.

108. Binder DK, Steinhauser C. Functional changes in astroglial cells in epilepsy. Glia. 2006;54(5):358-68.

109. Heinemann U, Kaufer D, Friedman A. Blood-brain barrier dysfunction, TGFbeta signaling, and astrocyte dysfunction in epilepsy. Glia. 2012;60(8):1251-7.

110. Garlanda C, Dinarello CA, Mantovani A. The interleukin-1 family: back to the future. Immunity. 2013:39(6):1003-18.

111. Kim Y-J, Hwang S-Y, Oh E-S, Oh S, Han I-O. IL-1beta, an immediate early protein secreted by activated microglia, induces iNOS/NO in C6 astrocytoma cells through p38 MAPK and NF-kappaB pathways. J Neurosci Res. 2006:84(5):1037-46.

112. Lau LT, Yu AC. Astrocytes produce and release interleukin-1, interleukin-6, tumor necrosis factor alpha and interferon-gamma following traumatic and metabolic injury. J Neurotrauma. 2001;18(3):351-9.

113. Miossec P, Cavender D, Ziff M. Production of interleukin 1 by human endothelial cells. J Immunol. 1986;136(7):2486-91.

114. John GR, Lee SC, Song X, Rivieccio M, Brosnan CF. IL-1-regulated responses in astrocytes: relevance to injury and recovery. Glia. 2005;49(2):161-76.

115. Konsman JP, Viques S, Mackerlova L, Bristow A, Blomqvist A. Rat brain vascular distribution of interleukin-1 type-1 receptor immunoreactivity: relationship to patterns of inducible cyclooxygenase expression by peripheral inflammatory stimuli. J Comp Neurol. 2004;472(1):113-29.

116. Pinteaux E, Parker LC, Rothwell NJ, Luheshi GN. Expression of interleukin-1 receptors and their role in interleukin-1 actions in murine microglial cells. J Neurochem. 2002;83(4):754-63.

117. Sato A, Ohtaki H, Tsumuraya T, Song D, Ohara K, Asano M, et al. Interleukin1 participates in the classical and alternative activation of microglia/ macrophages after spinal cord injury. J Neuroinflammation. 2012;9:65.

118. Srinivasan D, Yen J-H, Joseph DJ, Friedman W. Cell type-specific interleukin1beta signaling in the CNS. J Neurosci. 2004;24(29):6482-8.

119. Vela JM, Molina-Holgado E, Arevalo-Martin A, Almazan G, Guaza C. Interleukin-1 regulates proliferation and differentiation of oligodendrocyte progenitor cells. Mol Cell Neurosci. 2002;20(3):489-502.
120. Moynagh PN. The interleukin-1 signalling pathway in astrocytes: a key contributor to inflammation in the brain. J Anat. 2005;207(3):265-9.

121. Fan L, Young PR, Barone FC, Feuerstein GZ, Smith DH, Mclntosh TK. Experimental brain injury induces expression of interleukin-1 beta mRNA in the rat brain. Brain Res Mol Brain Res. 1995;30(1):125-30.

122. Kinoshita K, Chatzipanteli IK, Vitarbo E, Truettner JS, Alonso OF, Dietrich WD. Interleukin-1 beta messenger ribonucleic acid and protein levels after fluidpercussion brain injury in rats: importance of injury severity and brain temperature. Neurosurgery. 2002;51(1):195-203. discussion.

123. Ciallella JR, Ikonomovic MD, Paljug WR, Wilbur YI, Dixon CE, Kochanek PM, et al. Changes in expression of amyloid precursor protein and interleukin-1beta after experimental traumatic brain injury in rats. J Neurotrauma. 2002;19(12):1555-67.

124. Kamm K, Vanderkolk W, Lawrence C, Jonker M, Davis AT. The effect of traumatic brain injury upon the concentration and expression of interleukin1 beta and interleukin-10 in the rat. J Trauma. 2006;60(1):152-7.

125. Acosta SA, Tajiri N, Shinozuka K, Ishikawa H, Grimmig B, Diamond DM, et al. Long-term upregulation of inflammation and suppression of cell proliferation in the brain of adult rats exposed to traumatic brain injury using the controlled cortical impact model. PLoS One. 2013;8(1):e53376.

126. Frugier T, Morganti-Kossmann MC, O'Reilly D, McLean CA. In situ detection of inflammatory mediators in post mortem human brain tissue after traumatic injury. J Neurotrauma. 2010;27(3):497-507.

127. Holmin S, Soderlund J, Biberfeld P, Mathiesen T. Intracerebral inflammation after human brain contusion. Neurosurgery. 1998;42(2):291-8.

128. Winter CD, lannotti F, Pringle AK, Trikkas C, Clough GF, Church MK. A microdialysis method for the recovery of $\mathrm{IL}-1$ beta, $\mathrm{IL}-6$ and nerve growth factor from human brain in vivo. J Neurosci Methods. 2002;119(1):45-50.

129. Shiozaki T, Hayakata T, Tasaki O, Hosotubo H, Fuijita K, Mouri T, et al. Cerebrospinal fluid concentrations of anti-inflammatory mediators in earlyphase severe traumatic brain injury. Shock. 2005;23(5):406-10.

130. Hunt RF, Boychuk JA, Smith BN. Neural circuit mechanisms of posttraumatic epilepsy. Front Cell Neurosci. 2013;7:89. doi:10.3389/fncel.2013. 00089.

131. Clausen F, Hanell A, Bjork M, Hillered L, Mir AK, Gram H, et al. Neutralization of interleukin-1beta modifies the inflammatory response and improves histological and cognitive outcome following traumatic brain injury in mice. Eur J Neurosci. 2009;30(3):385-96.

132. Clausen F, Hanell A, Israelsson C, Hedin J, Ebendal T, Mir AK, et al. Neutralization of interleukin-1 beta reduces cerebral edema and tissue loss and improves late cognitive outcome following traumatic brain injury in mice. Eur J Neurosci. 2011;34(1):110-23.

133. Lazovic J, Basu A, Lin H-W, Rothstein RP, Krady JK, Smith MB, et al. Neuroinflammation and both cytotoxic and vasogenic edema are reduced in interleukin-1 type 1 receptor-deficient mice conferring neuroprotection. Stroke. 2005:36(10):2226-31.

134. Sanderson $\mathrm{KL}$, Raghupathi R, Saatman KE, Martin D, Miller G, Mclntosh TK. Interleukin-1 receptor antagonist attenuates regional neuronal cell death and cognitive dysfunction after experimental brain injury. J Cereb Blood Flow Metab. 1999;19(10):1118-25.

135. Helmy A, Guilfoyle MR, Carpenter KLH, Pickard JD, Menon DK, Hutchinson PJ. Recombinant human interleukin-1 receptor antagonist in severe traumatic brain injury: a phase II randomized control trial. J Cereb Blood Flow Metab. 2014:34(5):845-51.

136. Diamond ML, Ritter AC, Failla MD, Boles JA, Conley YP, Kochanek PM, et al. IL-1 beta associations with posttraumatic epilepsy development: a genetics and biomarker cohort study. Epilepsia. 2015;56(7):991-1001.

137. Dube CM, Ravizza T, Hamamura M, Zha Q, Keebaugh A, Fok K, et al. Epileptogenesis provoked by prolonged experimental febrile seizures: mechanisms and biomarkers. J Neurosci. 2010;30(22):7484-94.

138. Dube C, Vezzani A, Behrens M, Bartfai T, Baram TZ. Interleukin-1 beta contributes to the generation of experimental febrile seizures. Ann Neurol. 2005:57(1):152-5.

139. Zhu G, Okada M, Yoshida S, Mori F, Ueno S, Wakabayashi K, et al. Effects of interleukin-1 beta on hippocampal glutamate and GABA releases associated with Ca2 +-induced Ca2+ releasing systems. Epilepsy Res. 2006;71(2-3):107-16

140. Wetherington J, Serrano G, Dingledine R. Astrocytes in the epileptic brain. Neuron. 2008;58(2):168-78

141. Ferrari CC, Depino AM, Prada F, Muraro N, Campbell S, Podhajcer O, et al. Reversible demyelination, blood-brain barrier breakdown, and pronounced neutrophil recruitment induced by chronic IL-1 expression in the brain. Am J Pathol. 2004;165(5):1827-37. 
142. Proescholdt MG, Chakravarty S, Foster JA, Foti SB, Briley EM, Herkenham M. Intracerebroventricular but not intravenous interleukin-1beta induces widespread vascular-mediated leukocyte infiltration and immune signal mRNA expression followed by brain-wide glial activation. Neuroscience. 2002;112(3):731-49.

143. Quagliarello VJ, Wispelwey B, Long Jr WJ, Scheld WM. Recombinant human interleukin-1 induces meningitis and blood-brain barrier injury in the rat. Characterization and comparison with tumor necrosis factor. J Clin Invest. 1991;87(4):1360-6.

144. Shaftel SS, Carlson TJ, Olschowka JA, Kyrkanides S, Matousek SB, O'Banion MK. Chronic interleukin-1beta expression in mouse brain leads to leukocyte infiltration and neutrophil-independent blood brain barrier permeability without overt neurodegeneration. J Neurosci. 2007;27(35):9301-9.

145. Harting MT, Jimenez F, Adams SD, Mercer DW, Cox Jr CS. Acute, regional inflammatory response after traumatic brain injury: implications for cellular therapy. Surgery. 2008;144(5):803-13.

146. Lu K-T, Wang Y-W, Yang J-T, Yang Y-L, Chen H-I. Effect of interleukin-1 on traumatic brain injury-induced damage to hippocampal neurons. J Neurotrauma. 2005;22(8):885-95.

147. Pacifici R, Paris L, Di Carlo S, Bacosi A, Pichini S, Zuccaro P. Cytokine production in blood mononuclear cells from epileptic patients. Epilepsia. 1995;36(4):384-7.

148. Tanriverdi T, Uzan M, Sanus GZ, Baykara O, Is M, Ozkara C, et al. Lack of association between the IL1A gene (-889) polymorphism and outcome after head injury. Surg Neurol. 2006;65(1):7-10. discussion.

149. Haspolat S, Baysal Y, Duman O, Coskun M, Tosun O, Yegin O. Interleukin1alpha, interleukin-1beta, and interleukin-1Ra polymorphisms in febrile seizures. J Child Neurol. 2005;20(7):565-8.

150. Bianchi ME, Manfredi AA. High-mobility group box 1 (HMGB1) protein at the crossroads between innate and adaptive immunity. Immunol Rev. 2007;220:35-46.

151. Stros M. HMGB proteins: interactions with DNA and chromatin. Biochim Biophys Acta. 2010;1799(1-2):101-13.

152. Yanai H, Ban T, Taniguchi T. Essential role of high-mobility group box proteins in nucleic acid-mediated innate immune responses. J Intern Med. 2011;270(4):301-8

153. Goodwin GH, Sanders C, Johns EW. A new group of chromatin-associated proteins with a high content of acidic and basic amino acids. Eur J Biochem. 1973;38(1):14-9.

154. Gerlitz G, Hock R, Ueda T, Bustin M. The dynamics of HMG proteinchromatin interactions in living cells. Biochem Cell Biol. 2009;87(1):127-37.

155. Venters BJ, Pugh BF. How eukaryotic genes are transcribed. Crit Rev Biochem Mol Biol. 2009;44(2-3):117-41.

156. Calogero S, Grassi F, Aguzzi A, Voigtlander T, Ferrier P, Ferrari S, et al. The lack of chromosomal protein Hmg1 does not disrupt cell growth but causes lethal hypoglycaemia in newborn mice. Nat Genet. 1999;22(3):276-80.

157. Yang $\mathrm{H}$, Antoine DJ, Andersson U, Tracey KJ. The many faces of HMGB1: molecular structure-functional activity in inflammation, apoptosis, and chemotaxis. J Leukoc Biol. 2013;93(6):865-73.

158. Scaffidi P, Misteli T, Bianchi ME. Release of chromatin protein HMGB1 by necrotic cells triggers inflammation. Nature. 2002;418(6894):191-5.

159. Bonaldi T, Talamo F, Scaffidi P, Ferrera D, Porto A, Bachi A, et al. Monocytic cells hyperacetylate chromatin protein HMGB1 to redirect it towards secretion. EMBO J. 2003;22(20):5551-60.

160. Lu B, Nakamura T, Inouye K, Li J, Tang Y, Lundback P, et al. Novel role of PKR in inflammasome activation and HMGB1 release. Nature. 2012;488(7413):670-4.

161. Wang $\mathrm{H}$, Bloom O, Zhang M, Vishnubhakat JM, Ombrellino M, Che J, et al. HMG-1 as a late mediator of endotoxin lethality in mice. Science (New York, NY). 1999;285(5425):248-51.

162. Harris HE, Andersson U, Pisetsky DS. HMGB1: a multifunctional alarmin driving autoimmune and inflammatory disease. Nat Rev Rheumatol. 2012; 8(4):195-202.

163. Aronica E, Crino PB. Inflammation in epilepsy: clinical observations. Epilepsia. 2011;52 Suppl 3:26-32

164. Chiavegato A, Zurolo E, Losi G, Aronica E, Carmignoto G. The inflammatory molecules IL-1 beta and HMGB1 can rapidly enhance focal seizure generation in a brain slice model of temporal lobe epilepsy. Front Cell Neurosci. 2014;8;155.

165. Maroso M, Balosso S, Ravizza T, Liu J, Aronica E, lyer AM, et al. Toll-like receptor 4 and high-mobility group box-1 are involved in ictogenesis and can be targeted to reduce seizures. Nat Med. 2010;16(4):413-U91.
166. Iori V, Maroso M, Rizzi M, Iyer AM, Vertemara R, Carli M, et al. Receptor for advanced glycation endproducts is upregulated in temporal lobe epilepsy and contributes to experimental seizures. Neurobiol Dis. 2013;58:102-14.

167. Balosso S, Liu J, Bianchi ME, Vezzani A. Disulfide-containing high mobility group box-1 promotes n-methyl-d-aspartate receptor function and excitotoxicity by activating toll-like receptor 4-dependent signaling in hippocampal neurons. Antioxid Redox Signal. 2014;21(12):1726-40.

168. Tang D, Kang R, Zeh 3rd HJ, Lotze MT. High-mobility group box 1, oxidative stress, and disease. Antioxid Redox Signal. 2011;14(7):1315-35.

169. Waldbaum S, Patel M. Mitochondria, oxidative stress, and temporal lobe epilepsy. Epilepsy Res. 2010;88(1):23-45.

170. Chen G, Shi J, Jin W, Wang L, Xie W, Sun J, et al. Progesterone administration modulates TLRs/NF-kappa B signaling pathway in rat brain after cortical contusion. Ann Clin Lab Sci. 2008;38(1):65-74.

171. Okun E, Griffioen KJ, Lathia JD, Tang S-C, Mattson MP, Arumugam TV. Tolllike receptors in neurodegeneration. Brain Res Rev. 2009;59(2):278-92.

172. Chang ZL. Important aspects of toll-like receptors, ligands and their signaling pathways. Inflamm Res. 2010;59(10):791-808.

173. Lu Y-C, Yeh W-C, Ohashi PS. LPS/TLR4 signal transduction pathway. Cytokine. 2008;42(2):145-51.

174. Sha YG, Zmijewski J, Xu ZW, Abraham E. HMGB1 develops enhanced binding to cytokines. J Immunol. 2008;180(4):2531-7.

175. Garcia-Arnandis I, Guillen MI, Gomar F, Pelletier JP, Martel-Pelletier J, Alcaraz MJ. High mobility group box 1 potentiates the pro-inflammatory effects of interleukin-1 beta in osteoarthritic synoviocytes. Arthr Res Ther. 2010;12(4):R165.

176. Annegers JF, Grabow JD, Groover RV, Laws Jr ER, Elveback LR, Kurland LT. Seizures after head trauma: a population study. Neurology. 1980;30(7 Pt 1):683-9.

177. Shlosberg D, Benifla M, Kaufer D, Friedman A. Blood-brain barrier breakdown as a therapeutic target in traumatic brain injury. Nat Rev Neurol. 2010;6(7):393-403

178. Kelley BJ, Lifshitz J, Povlishock JT. Neuroinflammatory responses after experimental diffuse traumatic brain injury. J Neuropathol Exp Neurol. 2007:66(11):989-1001.

179. Friedman A, Kaufer D, Heinemann U. Blood-brain barrier breakdowninducing astrocytic transformation: novel targets for the prevention of epilepsy. Epilepsy Res. 2009;85(2-3):142-9.

180. Tomkins O, Feintuch A, Benifla M, Cohen A, Friedman A, Shelef I. Bloodbrain barrier breakdown following traumatic brain injury: a possible role in posttraumatic epilepsy. Cardiovasc Psychiatr Neurol. 2011;2011:765923.

181. Tomkins O, Shelef I, Kaizerman I, Eliushin A, Afawi Z, Misk A, et al. Bloodbrain barrier disruption in post-traumatic epilepsy. J Neurol Neurosurg Psychiatry. 2008;79(7):774-7.

182. Cacheaux LP, Ivens S, David Y, Lakhter AJ, Bar-Klein G, Shapira M, et al. Transcriptome profiling reveals TGF-beta signaling involvement in epileptogenesis. J Neurosci. 2009;29(28):8927-35.

183. Weissberg I, Wood L, Kamintsky L, Vazquez O, Milikovsky DZ, Alexander A, et al. Albumin induces excitatory synaptogenesis through astrocytic TGF-beta/ ALK5 signaling in a model of acquired epilepsy following blood-brain barrier dysfunction. Neurobiol Dis. 2015;78:115-25.

184. Ivens S, Kaufer D, Flores LP, Bechmann I, Zumsteg D, Tomkins O, et al. TGFbeta receptor-mediated albumin uptake into astrocytes is involved in neocortical epileptogenesis. Brain. 2007;130(Pt 2):535-47.

185. Barkai E, Grossman Y, Gutnick MJ. Long-term changes in neocortical activity after chemical kindling with systemic pentylenetetrazole: an in vitro study. J Neurophysiol. 1994;72(1):72-83.

186. Sanabria ERG, Silva AV, Spreafico R, Cavalheiro EA. Damage, reorganization, and abnormal neocortical hyperexcitability in the pilocarpine model of temporal lobe epilepsy. Epilepsia. 2002;43 Suppl 5:96-106.

187. Tigyi G, Hong L, Yakubu M, Parfenova H, Shibata M, Leffler CW. Lysophosphatidic acid alters cerebrovascular reactivity in piglets. Am J Phys. 1995:268(5 Pt 2):H2048-55.

188. Blobe GC, Schiemann WP, Lodish HF. Role of transforming growth factor beta in human disease. N Engl J Med. 2000;342(18):1350-8.

189. Gold LI, Parekh TV. Loss of growth regulation by transforming growth factor-beta (TGF-beta) in human cancers: studies on endometrial carcinoma. Semin Reprod Endocrinol. 1999;17(1):73-92.

190. Shi Y, Massague J. Mechanisms of TGF-beta signaling from cell membrane to the nucleus. Cell. 2003;113(6):685-700.

191. Szelenyi J. Cytokines and the central nervous system. Brain Res Bull. 2001;54(4):329-38 
192. Phillips DJ, Nguyen P, Adamides AA, Bye N, Rosenfeld JV, Kossmann T, et al. Activin a release into cerebrospinal fluid in a subset of patients with severe traumatic brain injury. J Neurotrauma. 2006;23(9):1283-94.

193. Brionne TC, Tesseur I, Masliah E, Wyss-Coray T. Loss of TGF-beta 1 leads to increased neuronal cell death and microgliosis in mouse brain. Neuron. 2003:40(6):1133-45.

194. Prehn JH, Bindokas VP, Marcuccilli CJ, Krajewski S, Reed JC, Miller RJ. Regulation of neuronal $\mathrm{BCl} 2$ protein expression and calcium homeostasis by transforming growth factor type beta confers wide-ranging protection on rat hippocampal neurons. Proc Natl Acad Sci U S A. 1994;91(26):12599-603.

195. Plata-Salaman CR, llyin SE, Turrin NP, Gayle D, Flynn MC, Romanovitch AE, et al. Kindling modulates the IL-1beta system, TNF-alpha, TGF-beta1, and neuropeptide mRNAs in specific brain regions. Brain Res Mol Brain Res. 2000;75(2):248-58.

196. Aronica E, van Vliet EA, Mayboroda OA, Troost D, da Silva FH, Gorter JA. Upregulation of metabotropic glutamate receptor subtype mGluR3 and mGluR5 in reactive astrocytes in a rat model of mesial temporal lobe epilepsy. Eur J Neurosci. 2000;12(7):2333-44.

197. Frigerio F, Frasca A, Weissberg I, Parrella S, Friedman A, Vezzani A, et al. Long-lasting pro-ictogenic effects induced in vivo by rat brain exposure to serum albumin in the absence of concomitant pathology. Epilepsia. 2012;53(11):1887-97.

198. Jin X, Prince DA, Huguenard JR. Enhanced excitatory synaptic connectivity in layer $v$ pyramidal neurons of chronically injured epileptogenic neocortex in rats. J Neurosci. 2006;26(18):4891-900.

199. Scheff SW, Price DA, Hicks RR, Baldwin SA, Robinson S, Brackney C. Synaptogenesis in the hippocampal CA1 field following traumatic brain injury. J Neurotrauma. 2005;22(7):719-32.

200. Schoderboeck L, Adzemovic M, Nicolussi E-M, Crupinschi C, Hochmeister S, Fischer $\mathrm{M}-\mathrm{T}$, et al. The "window of susceptibility" for inflammation in the immature central nervous system is characterized by a leaky blood-brain barrier and the local expression of inflammatory chemokines. Neurobiol Dis. 2009;35(3):368-75.

201. Galea I, Bechmann I, Perry VH. What is immune privilege (not)? Trends Immunol. 2007;28(1):12-8.

202. Umehara F, Qin YF, Goto M, Wekerle H, Meyermann R. Experimental autoimmune encephalomyelitis in the maturing central-nervous-systemtransfer of myelin basic protein-specific T-line lymphocytes to neonatal lewis rats. Lab Investig. 1990;62(2):147-55.

203. Anthony D, Dempster R, Fearn S, Clements J, Wells G, Perry VH, et al. CXC chemokines generate age-related increases in neutrophil-mediated brain inflammation and blood-brain barrier breakdown. Curr Biol. 1998:8(16):923-6.

204. Anthony DC, Bolton SJ, Fearn S, Perry VH. Age-related effects of interleukin1 beta on polymorphonuclear neutrophil-dependent increases in bloodbrain barrier permeability in rats. Brain. 1997;120:435-44.

205. Mollgard K, Saunders NR. The development of the human blood-brain and blood-CSF barriers. Neuropathol Appl Neurobiol. 1986;12(4):337-58.

206. Elhofy A, Wang J, Tani M, Fife BT, Kennedy KJ, Bennett J, et al. Transgenic expression of CCL2 in the central nervous system prevents experimental autoimmune encephalomyelitis. J Leukoc Biol. 2005:77(2):229-37.

207. Karpus WJ, Lukacs NW, McRae BL, Strieter RM, Kunkel SL, Miller SD. An important role for the chemokine macrophage inflammatory protein-1 alpha in the pathogenesis of the T cell-mediated autoimmune disease, experimental autoimmune encephalomyelitis. J Immunol. 1995;155(10):5003-10.

208. Luo Y, Fischer FR, Hancock WW, Dorf ME. Macrophage inflammatory protein-2 and $\mathrm{KC}$ induce chemokine production by mouse astrocytes. J Immunol. 2000;165(7):4015-23.

209. Levy O. Innate immunity of the newborn: basic mechanisms and clinical correlates. Nat Rev Immunol. 2007;7(5):379-90.

210. Berger RP, Ta'asan S, Rand A, Lokshin A, Kochanek P. Multiplex assessment of serum biomarker concentrations in well-appearing children with inflicted traumatic brain injury. Pediatr Res. 2009;65(1):97-102.

211. Buttram SDW, Wisniewski SR, Jackson EK, Adelson PD, Feldman K, Bayir H, et al. Multiplex assessment of cytokine and chemokine levels in cerebrospinal fluid following severe pediatric traumatic brain injury: effects of moderate hypothermia. J Neurotrauma. 2007;24(11):1707-17.

212. Whalen MJ, Carlos TM, Kochanek PM, Wisniewski SR, Bell MJ, Clark RS, et al. Interleukin-8 is increased in cerebrospinal fluid of children with severe head injury. Crit Care Med. 2000;28(4):929-34.
213. Perry VH, Hume DA, Gordon S. Immunohistochemical localization of macrophages and microglia in the adult and developing mouse brain. Neuroscience. 1985;15(2):313-26.

214. Lawson LJ, Perry VH. The unique characteristics of inflammatory responses in mouse brain are acquired during postnatal development. Eur J Neurosci. 1995;7(7):1584-95.

215. Oppenheim R. Neuronal cell death and some related regressive phenomena during neurogenesis: a selective historical review and progress report. Oxford: Oxford University Press; 1981

216. Unkeless JC. Characterization of a monoclonal antibody directed against mouse macrophage and lymphocyte Fc receptors. J Exp Med. 1979;150(3):580-96.

217. Johnston MV, Trescher WH, Ishida A, Nakajima W. Neurobiology of hypoxicischemic injury in the developing brain. Pediatr Res. 2001;49(6):735-41.

218. Brooks-Kayal AR. Rearranging receptors. Epilepsia. 2005;46 Suppl 7:29-38.

219. Ben-Ari Y. Excitatory actions of gaba during development: the nature of the nurture. Nat Rev Neurosci. 2002;3(9):728-39.

220. Dzhala VI, Staley KJ. Excitatory actions of endogenously released GABA contribute to initiation of ictal epileptiform activity in the developing hippocampus. J Neurosci. 2003;23(5):1840-6.

221. Khazipov R, Khalilov I, Tyzio R, Morozova E, Ben-Ari Y, Holmes GL. Developmental changes in GABAergic actions and seizure susceptibility in the rat hippocampus. Eur J Neurosci. 2004;19(3):590-600.

222. Ruffolo G, lyer A, Cifelli P, Roseti C, Muhlebner A, van Scheppingen J, et al. Functional aspects of early brain development are preserved in tuberous sclerosis complex (TSC) epileptogenic lesions. Neurobiol Dis. 2016;95:93-101.

223. Hernan AE, Holmes GL. Antiepileptic drug treatment strategies in neonatal epilepsy. Prog Brain Res. 2016;226:179-93.

224. Stamboulian-Platel S, Legendre A, Chabrol T, Platel J-C, Pernot F, Duveau V, et al. Activation of GABA(A) receptors controls mesiotemporal lobe epilepsy despite changes in chloride transporters expression: in vivo and in silico approach. Exp Neurol. 2016;284:11-28.

225. Erecinska $M$, Cherian S, Silver IA. Energy metabolism in mammalian brain during development. Prog Neurobiol. 2004;73(6):397-445.

226. Holmes GL. Effects of seizures on brain development: lessons from the laboratory. Pediatr Neurol. 2005;33(1):1-11.

227. Szot P, White SS, McCarthy EB, Turella A, Rejniak SX, Schwartzkroin PA. Behavioral and metabolic features of repetitive seizures in immature and mature rats. Epilepsy Res. 2001;46(3):191-203.

228. Liu Z, Stafstrom CE, Sarkisian M, Tandon P, Yang Y, Hori A, et al. Agedependent effects of glutamate toxicity in the hippocampus. Brain Research. Dev Brain Res. 1996;97(2):178-84.

229. Galic MA, Riazi K, Heida JG, Mouihate A, Fournier NM, Spencer SJ, et al. Postnatal inflammation increases seizure susceptibility in adult rats. J Neurosci. 2008;28(27):6904-13.

230. Harre EM, Galic MA, Mouihate A, Noorbakhsh F, Pittman QJ. Neonatal inflammation produces selective behavioural deficits and alters N-methyl-Daspartate receptor subunit mRNA in the adult rat brain. Eur J Neurosci. 2008;27(3):644-53.

231. Insel TR, Miller LP, Gelhard RE. The ontogeny of excitatory amino-acid receptors in rat forebrain.1. N-methyl-D-aspartate and quisqualate receptors. Neuroscience. 1990;35(1):31-43.

232. Flint AC, Maisch US, Weishaupt JH, Kriegstein AR, Monyer H. NR2A subunit expression shortens NMDA receptor synaptic currents in developing neocortex. J Neurosci. 1997;17(7):2469-76.

233. Monyer H, Burnashev N, Laurie DJ, Sakmann B, Seeburg PH. Developmental and regional expression in the rat brain and functional-properties of 4 NMDA receptors. Neuron. 1994;12(3):529-40.

234. Hestrin S. Developmental regulation of NMDA receptor-mediated synaptic currents at a central synapse. Nature. 1992;357(6380):686-9.

235. Pitkanen A, Mclntosh TK. Animal. models of post-traumatic epilepsy. J Neurotrauma. 2006;23(2):241-61.

236. Golarai G, Greenwood AC, Feeney DM, Connor JA. Physiological and structural evidence for hippocampal involvement in persistent seizure susceptibility after traumatic brain injury. J Neurosci. 2001;21(21):8523-37.

237. Cernak I, Vink R, Zapple DN, Cruz MI, Ahmed F, Chang T, et al. The pathobiology of moderate diffuse traumatic brain injury as identified using a new experimental model of injury in rats. Neurobiol Dis. 2004;17(1):29-43.

238. Pitkanen A, Bolkvadze T, Immonen R. Anti-epileptogenesis in rodent posttraumatic epilepsy models. Neurosci Lett. 2011;497(3):163-71. 
239. Hunt RF, Scheff SW, Smith BN. Posttraumatic epilepsy after controlled cortical impact injury in mice. Exp Neurol. 2009;215(2):243-52

240. Annegers JF, Hauser WA, Coan SP, Rocca WA. A population-based study of seizures after traumatic brain injuries. N Engl J Med. 1998;338(1):20-4.

241. Bolkvadze T, Pitkanen A. Development of post-traumatic epilepsy after controlled cortical impact and lateral fluid-percussion-induced brain injury in the mouse. J Neurotrauma. 2012;29(5):789-812.

242. D'Ambrosio R, Eastman CL, Fattore C, Perucca E. Novel frontiers in epilepsy treatments: preventing epileptogenesis by targeting inflammation. Expert Rev Neurother. 2013;13(6):615-25.

243. Polderman $\mathrm{KH}$. Mechanisms of action, physiological effects, and complications of hypothermia. Crit Care Med. 2009;37(7):S186-202.

244. Atkins CM, Truettner JS, Lotocki G, Sanchez-Molano J, Kang Y, Alonso OF, et al. Post-traumatic seizure susceptibility is attenuated by hypothermia therapy. Eur J Neurosci. 2010;32(11):1912-20.

245. D'Ambrosio R, Eastman CL, Darvas F, Fender JS, Verley DR, Farin FM, et al. Mild passive focal cooling prevents epileptic seizures after head injury in rats. Ann Neurol. 2013;73(2):199-209.

246. Beattie EC, Stellwagen D, Morishita W, Bresnahan JC, Ha BK, Von Zastrow M, et al. Control of synaptic strength by glial TNF alpha. Science. 2002;295(5563):2282-5.

247. Jiang JX, Yang MS, Quan Y, Gueorguieva P, Ganesh T, Dingledine R. Therapeutic window for cyclooxygenase-2 related anti-inflammatory therapy after status epilepticus. Neurobiol Dis. 2015;76:126-36.

248. Song Y, Pimentel C, Walters K, Boller L, Ghiasvand S, Liu J, et al. Neuroprotective levels of IGF-1 exacerbate epileptogenesis after brain injury. Sci Rep. 2016;6:32095.

249. Alyu F, Dikmen M. Inflammatory aspects of epileptogenesis: contribution of molecular inflammatory mechanisms. Acta Neuropsychiatr. 2016:3:1-16. doi: 10.1017/neu.2016.47.

250. Kaltschmidt B, Widera D, Kaltschmidt C. Signaling via NF-kappa B in the nervous system. Biochim Biophys Acta Mol Cell Res. 2005;1745(3):287-99.

\section{Submit your next manuscript to BioMed Central and we will help you at every step:}

- We accept pre-submission inquiries

- Our selector tool helps you to find the most relevant journal

- We provide round the clock customer support

- Convenient online submission

- Thorough peer review

- Inclusion in PubMed and all major indexing services

- Maximum visibility for your research

Submit your manuscript at www.biomedcentral.com/submit

) Biomed Central 